\title{
THE BEHAVIOR OF THE SPREAD BETWEEN TREASURY BILL RATES AND PRIVATE MONEY MARKET RATES SINCE 1978
}

\author{
Timothy Q. Cook and Thomas A. Lawler*
}

The Treasury bill rate is generally viewed as the representative money market rate. For this reason bill rates are almost always used in studies of the determinants of short-term interest rate levels and spreads, 'and bill rates are typically used as the index rate for variable-rate financial contracts. ${ }^{2}$ Despite this central role accorded Treasury bill rates, they frequently diverge greatly from other high-grade money market yields of comparable maturity. Furthermore, this differential is subject to abrupt change. These aspects of the spread are illustrated in Chart 1 , which uses the three-month prime negotiable CD rate $(\mathrm{RCD})$ as the private money market rate. ${ }^{3}$

An earlier paper by Cook [7] provided an explanation for the spread in the period prior to 1978 . According to this explanation, prior to 1978 most individual investors were unable to invest in private money market securities because of the high minimum denomination of those securities. Hence, their demand for T-bills was related to the spread between Treasury bill rates and regulated ceiling rates on small time deposits rather than to the spread between

\footnotetext{
* Timothy Q. Cook is Vice President, Federal Reserve Bank of Richmond, and Thomas A. Lawler is Senior Financial Economist, Federal National Mortgage Association.
}

'In particular, the spread between private money rates and bill rates is used as a measure of the default-risk premium on private securities [20]; the bill rate is generally used to test various hypotheses about the effect of such economic variables as the rate of inflation or the money supply on the general level of short-term interest rates $[9,18]$; and bill rates are always used to test hypotheses about the determinants of money market yield curves $[11,13]$.

${ }^{2}$ For example, the Treasury bill rate is often used as the determinant of the yield on adjustable-rate mortgages. Also, many banks and nonfinancial corporations have recently issued floating-rate notes with rates tied to Treasury bill rates.

${ }^{3}$ The $\mathrm{CD}$ rate is used in this article as a representative private money market rate. Commercial paper rates behave similarly to $C D$ rates and statements in this paper regarding the spread between the $\mathrm{CD}$ and bill rate apply equally well to the spread between the commercial paper and bill rates. bill rates and private money rates. When interest rates rose above deposit rate ceilings at the depository institutions, the resulting "disintermediation" and massive purchases of bills by individuals caused bill rates to fall relative to private money rates. ${ }^{4}$

An empirical implication of this explanation was that the spread between private money rates and bill rates increased in periods of disintermediation when bill rates rose relative to the ceiling rates on small time deposits. The evidence from the earlier study provided strong support for this implication. Because ceiling rates on time deposits were fairly inflexible prior to 1978, this explanation also implied a positive relationship between the level of rates and the spread. As shown in Chart 1, this was clearly true in the pre-1978 period.

Institutional and regulatory developments in 1978 eliminated the underpinnings of this explanation by providing individuals with ways to earn money market rates without investing in Treasury bills. Most importantly, that year saw the beginning of the rise in popularity of money market mutual funds. (Money market fund shares grew from \$3.3 billion at the end of 1977 to $\$ 9.5$ billion at the end of 1978 to $\$ 42.9$ billion at the end of 1979.) Also, in June of 1978 depository institutions were first allowed to offer money market certificates in denominations as low as $\$ 10,000$ with an interest rate tied to the 6month T-bill rate.

Chart 1 shows that since 1978 the spread has not approached the levels reached in 1974. Nevertheless, the spread has been very large at times and it has

\footnotetext{
${ }^{4}$ This explanation of the spread in periods of disintermediation raises an obvious question: Why didn't other investors sell their bills and buy private money market securities, thereby offsetting the impact of individual purchases on the spread? In fact, other investors in Treasury bills did react to the rise in the spread in periods of disintermediation by decreasing their holdings of bills, but this reaction was insufficient to eliminate the large movements in the spread caused by sharp increases in purchases of bills by individuals. This question is discussed in detail in [7].
} 


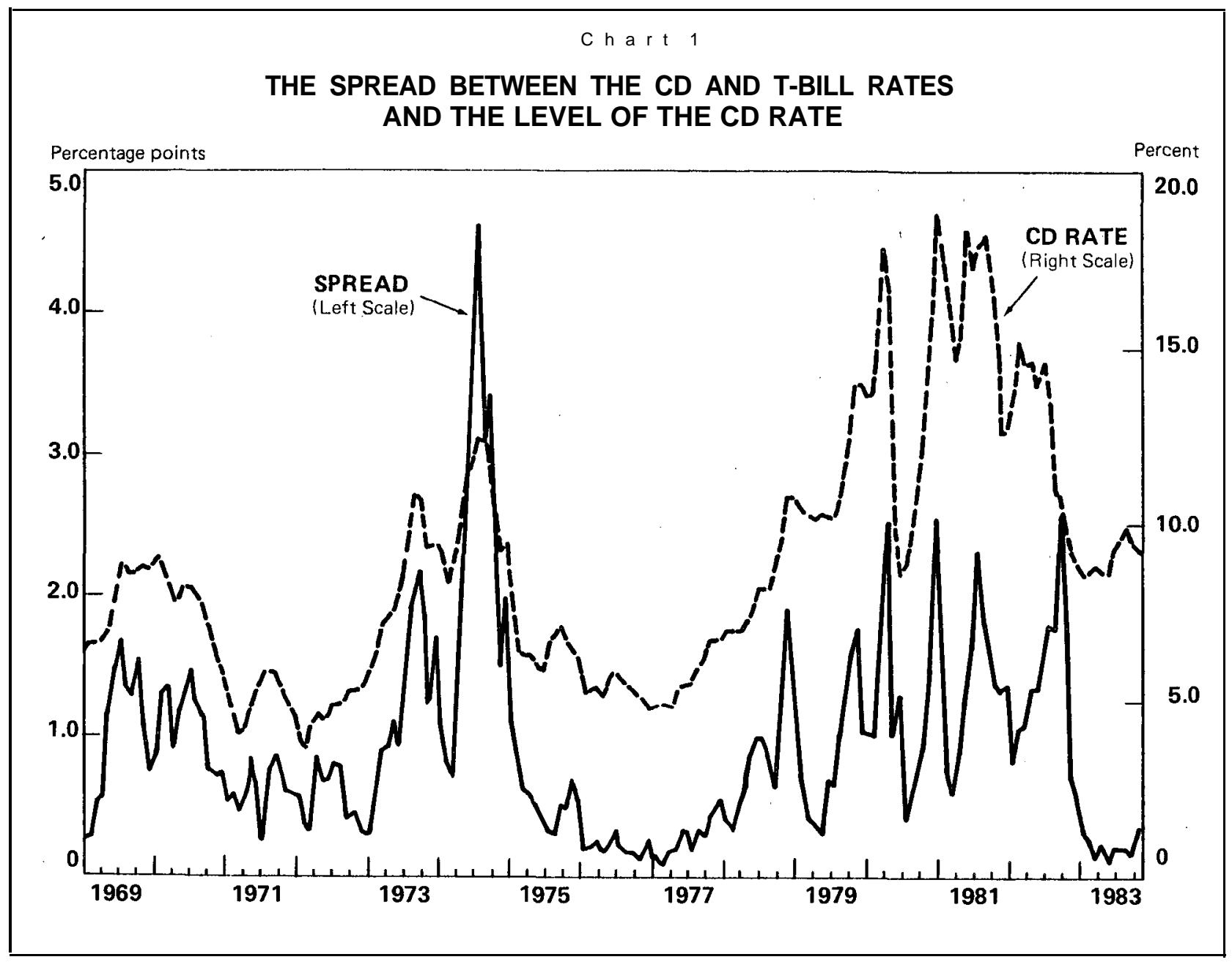

been even more volatile than in the earlier period. A number of times it has exceeded 200 basis points and then fallen sharply, sometimes within a couple of months, to well below 100 basis points. Also, the spread in the post-1978 period has continued to show a tendency to move with the level of interest rates, although a given level of interest rates has generally been associated with a smaller spread than in the earlier period.

This article examines the behavior of the spread in the post-1978 period using models that assume, contrary to the situation in the earlier period, that all investors can freely choose between Treasury bills and private money market securities. The major conclusion is that movement in the spread can be fairly well explained in this period under this assumption by default risk, taxes, and the relative supply of Treasury bills. Section I presents three models of the spread and discusses institutional information relevant to each. Section II looks briefly at the behavior of two types of investors in the bill market. Section III reports regression results for the three models. Section IV discusses the effect on the spread of the introduction of money market deposit accounts in late 1982.

\section{I.}

\section{MODEIS OF THE SPREAD IN THE POST-1978 PERIOD}

This section discusses three models of the spread between the rate on private money market securities (RMM) and the rate on Treasury bills (RTB). All three models assume that investors can choose freely between investing in private money market securities or bills. The first model focuses on default risk, while the second looks at a combination of default risk and taxes. Both models assume that all investors react the same to any given RMM-RTB spread. The third model drops this assumption. 
The focus throughout is on the demand for Treasury bills as a function of the RMM-RTB spread. It is assumed that the relative supply of Treasury bills is not sensitive to the spread, i.e., that the ratio of bills to total money market securities supplied is completely inelastic with respect to the spread. Gaps between U. S. government expenditures and receipts are the primary determinant of the amount of T-bills issued; while the Treasury at times alters the average maturity of U. S. Treasury debt, there is no evidence that such decisions are influenced by the RMM-RTB spread. Furthermore, it is reasonable to assume that the aggregate supply of private money market securities is not varied in reaction to movements in the RMM-RTB spread. (This latter assumption is discussed below.)

\section{Default-Risk Model}

The simplest view of the RMM-RTB spread in the post-1978 period is that it results solely from default risk on private money market securities. Treasury bills are backed by the full faith and credit of the U. S. government and are generally considered default free. In contrast, private money market securities such as CDs or commercial paper are backed by the promise of private corporations and, consequently, there is a general perception that default is possible on these securities.

Since investors care about expected, not promised, yields, they demand a higher promised yield on private money securities than on bills in order to offset the perceived risk of default and to equalize expected returns. Investors may also demand an additional premium for holding a riskier asset. The extra yield required by investors because of these factors is called the default-risk premium. According to the defaultrisk model, the RMM-RTB spread is a direct measure of this default-risk premium (DRP) on. private money market securities :

$$
\text { (1) } \mathrm{RMM}-\mathrm{RTB}=\mathrm{DRP} \text {. }
$$

Hence, according to this model, movements in the spread simply reflect movements in DRP. Figure 1 illustrates the simple default-risk model of the spread. For any value of the default-risk premium the demand curve for T-bills is infinitely elastic with respect to the RMM-RTB spread. This implies that shifts in the relative supply of bills have no effect on the spread.

The default-risk premium on private money securities is dependent on the attitudes of investors, which are not directly measurable. However, the simple default-risk model of the RMM-RTB spread can be evaluated by comparing it to yield spreads that are solely a function of default risk: if the default-risk model is correct, the RMM-RTB spread should behave similarly to these spreads. ${ }^{5}$ One money market default-risk spread that has been available since the beginning of 1974 is the spread between the onemonth medium-grade and prime-grade commercial paper rates (CPS). Chart 2 compares this spread to the RMM-RTB spread. ${ }^{6}$ The chart shows that the RMM-RTB spread does frequently move with the commercial paper rate spread. There are periods, however, such as mid-1980 through the end of 1981, when the RMM-RTB spread behaves very differently than the commercial paper rate spread.

\section{Tax and Risk Model}

The preceding discussion assumes that interest income earned on Treasury bills and private money market securities is taxed equally, which is true at the federal level. At the state and local level, however, interest income on T-bills is exempt from income taxes while interest income on private money market securities is not. Individual income tax rates

\footnotetext{
${ }^{5}$ These spreads typically rise in periods of recession and fall in periods of economic expansion. See Van Horne [2 1 ]

${ }^{6}$ The commercial paper rate spread is only available beginning in 1974 and there are no other yield series available to construct short-term default-risk spreads. Hence the chart starts in 1974.
}

Figure 1

\section{DEFAULT-RISK MODEL}

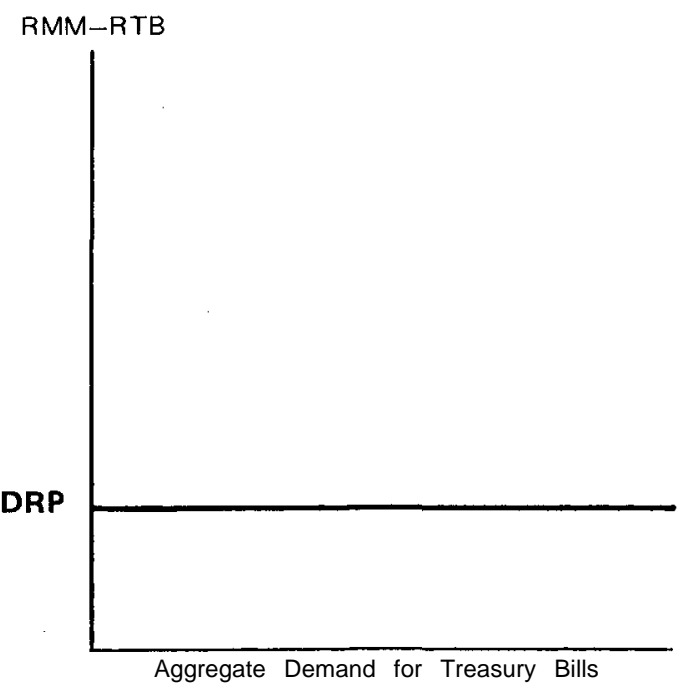




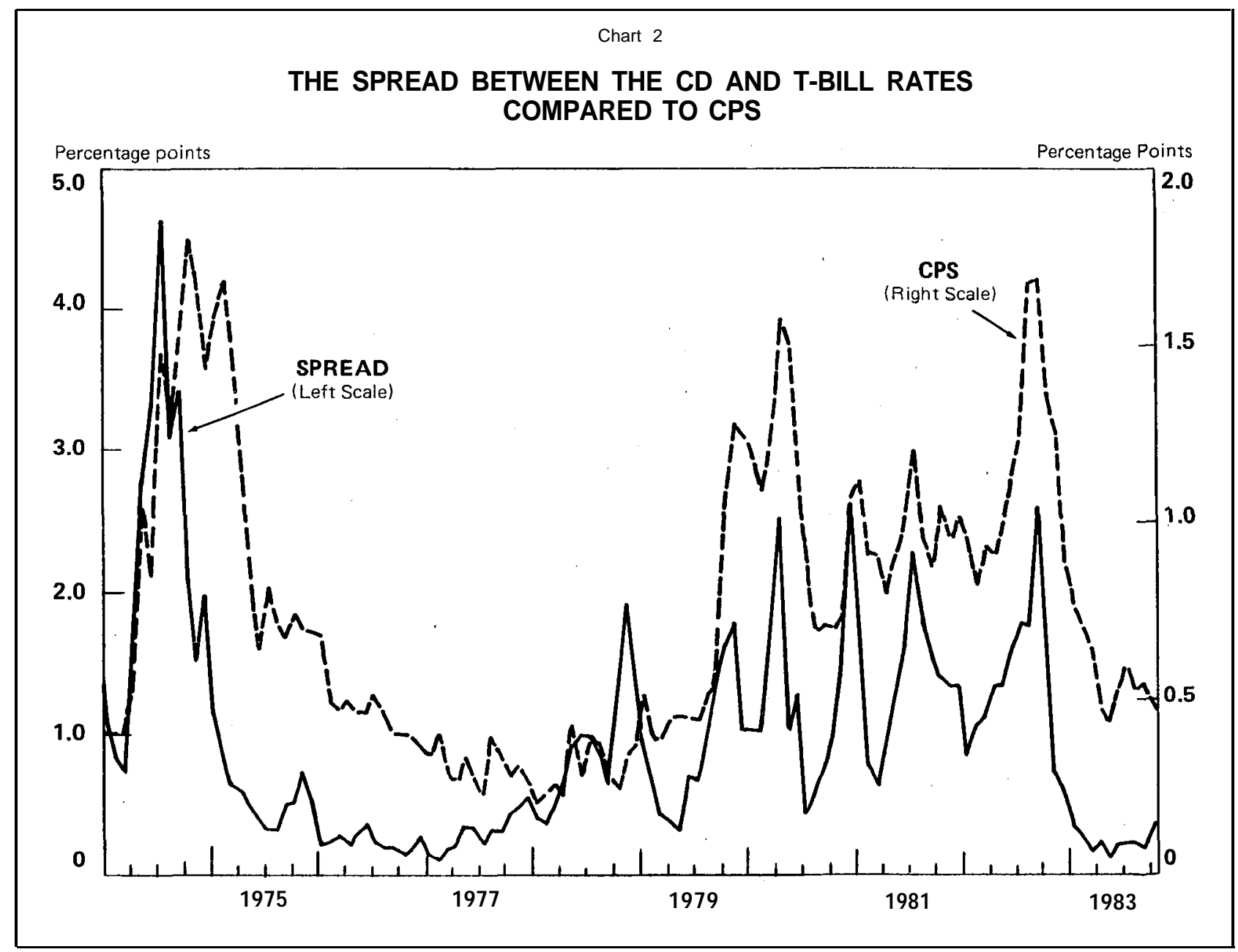

applied to interest income range across states from as low as zero to as high as 17 percent. These rates are shown in Table I as of October 1979. ${ }^{7}$ In some cases there are also local income tax rates; for example, in New York City the highest marginal local income tax rate exceeds 4 percent.

Despite the exemption of T-bill interest income from state and local taxation, there are three categories of investors who do not pay a higher tax rate on interest income of private money market securities than bills. The first includes investors who are not subject to state and local taxes, namely state and local governments and foreign investors. The second

${ }^{7}$ The tax rates shown are for the highest marginal tax rates. However, in almost all states the maximum tax rate-or one very close to it-is reached at a relatively low income. (The only exceptions are Alaska, Delaware, Louisiana, New Mexico, and West Virginia.) Hence, one can make the assumption that, in general, interest income on private money market investments in a given state is taxed at the highest marginal tax rate in that state. includes investors that pay a "franchise" or "excise" tax that in fact requires them to pay state taxes on interest earned on T-bills. ${ }^{8}$ Commercial banks in 28 states, including most of the heavily populated states, pay such a tax. And in 17 states there is a franchise tax on nonfinancial corporate income.'

The third type of investor taxed equally on interest income of T-bills and private money securities is money market fund (MMF) shareholders. All interest earned through investment in money market funds, including T-bill interest income, is subject to state and local income taxes. Consequently, an investor owning shares in a money market fund that holds T-bills must pay all applicable state and local taxes on the interest income, even though the investor

\footnotetext{
${ }^{8}$ These taxes function exactly like an income tax and were instituted expressly to get around the prohibition of state and local taxes on interest income of federal securities. See [4] and [15].

${ }^{9}$ These states are listed in $[6$, p. 652].
} 
Table I

\section{STATE INDIVIDUAL TAX RATES ON INTEREST INCOME}

(As of October 1, 1979)

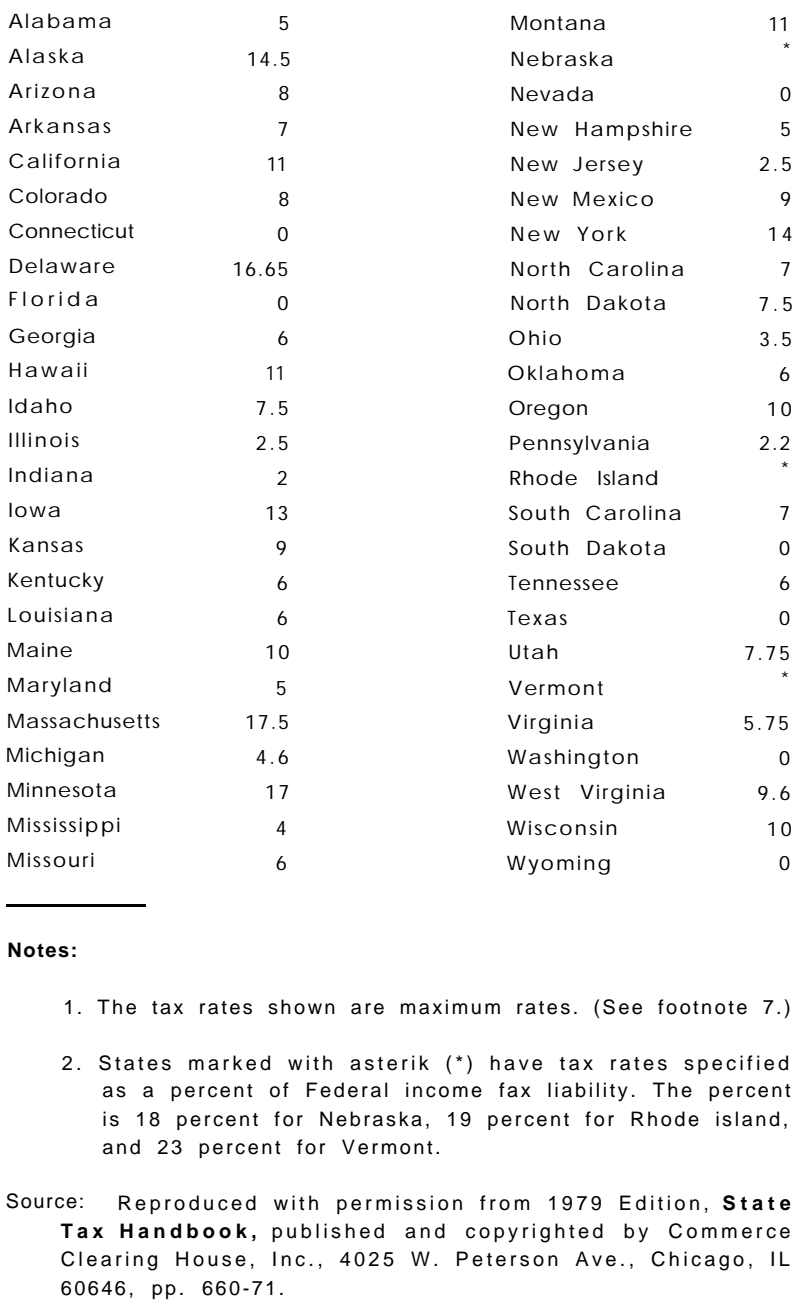

would not have to pay state and local taxes on that income if he purchased the T-bills directly.

The implications of the wide range of relative tax rates on T-bill versus private interest income for the determination of RMM-RTB spread will be considered below. For the present consider the case in which all investors are subject to the same marginal state and local tax rate of $t$ on private interest income; then the relationship between RMM and RTB would be

$$
\begin{array}{ll}
\text { (2) } \mathrm{RMM}(1-\mathrm{t})=\mathrm{RTB} & \text { or } \\
\text { (2a) } \mathrm{RMM}-\mathrm{RTB}=\mathrm{tRMM} & \text { or } \\
\text { (2b) } \mathrm{RMM} / \mathrm{RTB}=1 /(1-\mathrm{t}) . &
\end{array}
$$

Equation (2a) states that the RMM-RTB spread is positively related to the level of interest rates; the after-tax yields will remain equal only if the beforetax yield spread rises or falls in proportion to changes in the level of interest rates. Equation (2b) indicates that the ratio of RMM to RTB is constant over time when taxes are the only factor affecting the spread and marginal income tax rates are the same for all investors. $^{10}$

Chart 1 demonstrates that the RMM-RTB spread does tend to move with the level of interest rates. Chart 3, which plots the ratio of the three-month $\mathrm{CD}$ rate to the three-month $\mathrm{T}$-bill rate, illustrates that this' ratio is not constant. Although variability of the $\mathrm{RMM} / \mathrm{RTB}$ ratio is inconsistent with the simple tax model, the $\mathrm{RMM} / \mathrm{RTB}$ ratio in the post-1978 period has been much less variable than the RMMRTB spread. Moreover, the ratio, unlike the spread, is not strongly correlated to the level of rates over this period."

Of course, this simple tax model is deficient in that it ignores the effect of the default-risk premium on the spread. The tax and default-risk models can be joined by combining equations (1) and (2) :

$$
\begin{aligned}
& \text { (3) } \mathrm{RMM}(1-\mathrm{t})=\mathrm{RTB}+\mathrm{DRP} \text { or } \\
& \text { (3a) } \mathrm{RMM}-\mathrm{RTB}=\mathrm{tRMM}+\mathrm{DRP} \text { or } \\
& \text { (3b) } \mathrm{RMM} / \mathrm{RTB}=1 /(1-\mathrm{t})+ \\
& \text { DRP/RTB (1-t). }
\end{aligned}
$$

In this tax and risk model, the RMM-RTB spread is positively associated with the level of interest rates as in the simple tax model. However, in equation

\footnotetext{
${ }^{10}$ Suppose an investor is subject to a marginal federal income tax rate of $t_{f}$ and a marginal state income tax rate of $t_{s}$. State taxes paid can be deducted from federal income taxes. Hence, if the investor pays state income tax on private money market securities but not on Treasury bills, then the before-tax yields on Treasury bills and private money market securities that result in equal after-tax yields will be:$$
\text { R M M ( } \left.1-t_{\mathrm{f}}-\mathrm{t}_{\mathrm{s}}+\mathrm{t}_{\mathrm{f}} \mathrm{t}_{\mathrm{s}}\right)=\mathrm{RTB}\left(1-\mathrm{t}_{\mathrm{f}}\right)
$$

which can be reduced to:

$$
\text { R M M ( } \left.1-t_{s}\right)=\text { R T B , }
$$

which is the formula in the text.

${ }^{11}$ For the period from January 1979 through June 1983 the correlation coefficient between the RMM-RTB spread and the level of the Treasury bill rate is .520 . However, the correlation coefficient between the ratio and the level of the bill rate is only .068. (Note in Chart 3 that in the pre-1978 period the RMM/RTB ratio is as volatile as the spread and that it is also highly correlated with the level of rates. Over the $1974-77$ period the correlation coefficient between the spread and the level of the bill rate is .799 while the correlation coefficient between the ratio and the level of the bill rate is .758.)
} 


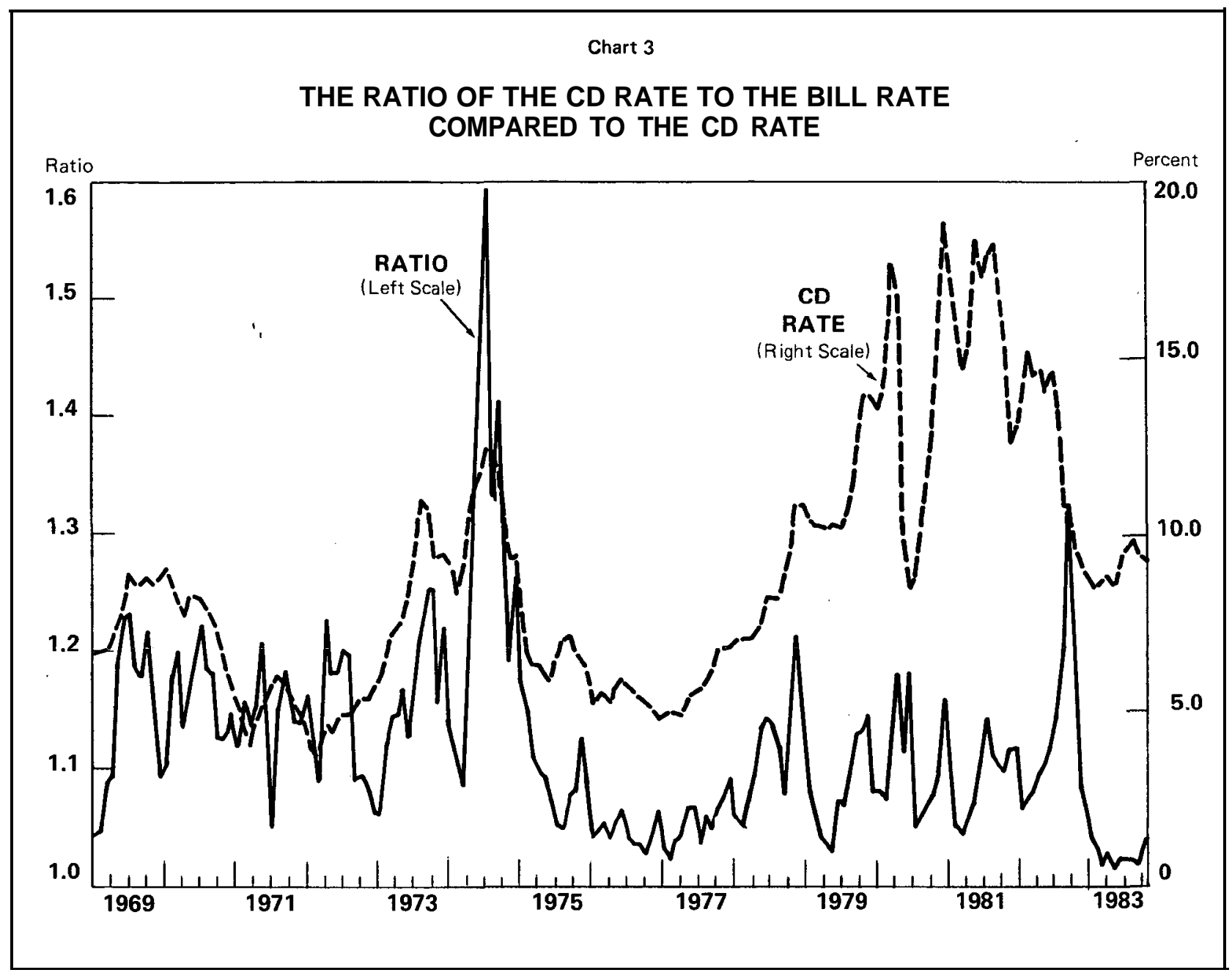

(3b) the $\mathrm{RMM} / \mathrm{RTB}$ ratio is not constant but changes with the DRP/RTB ratio.

Figure 2 illustrates the aggregate demand curve for T-bills implied by the combination of the defaultrisk and tax models. As the figure shows, at any given level of interest rates and default-risk premium, the demand for T-bills is infinitely elastic with respect to the RMM-RTB spread. If RMM rises and the default-risk premium remains unchanged, then the whole demand curve simply shifts upward by an amount equal to the product of the tax rate times RMM. Moreover, it can be seen from Figure 2 that changes in the relative supply of T-bills, if unaccompanied by changes in the level of interest rates or default-risk premium, have no effect on the RMMRTB spread.

Chart 4 compares the $\mathrm{RMM} / \mathrm{RTB}$ ratio to the ratio of the commercial paper spread and RTB in the 1979-83 period. The two series move fairly closely together over the whole 1979-83 period, suggesting

Figure 2

RISK AND TAX MODEL

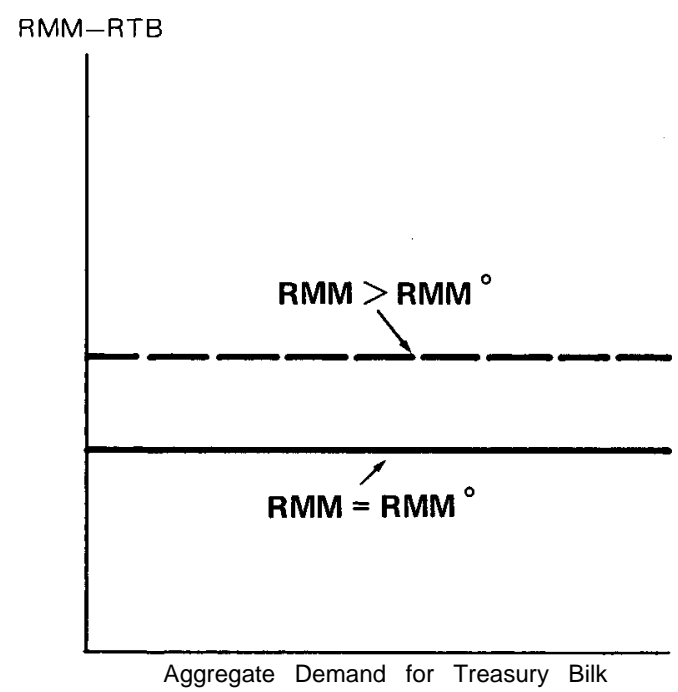




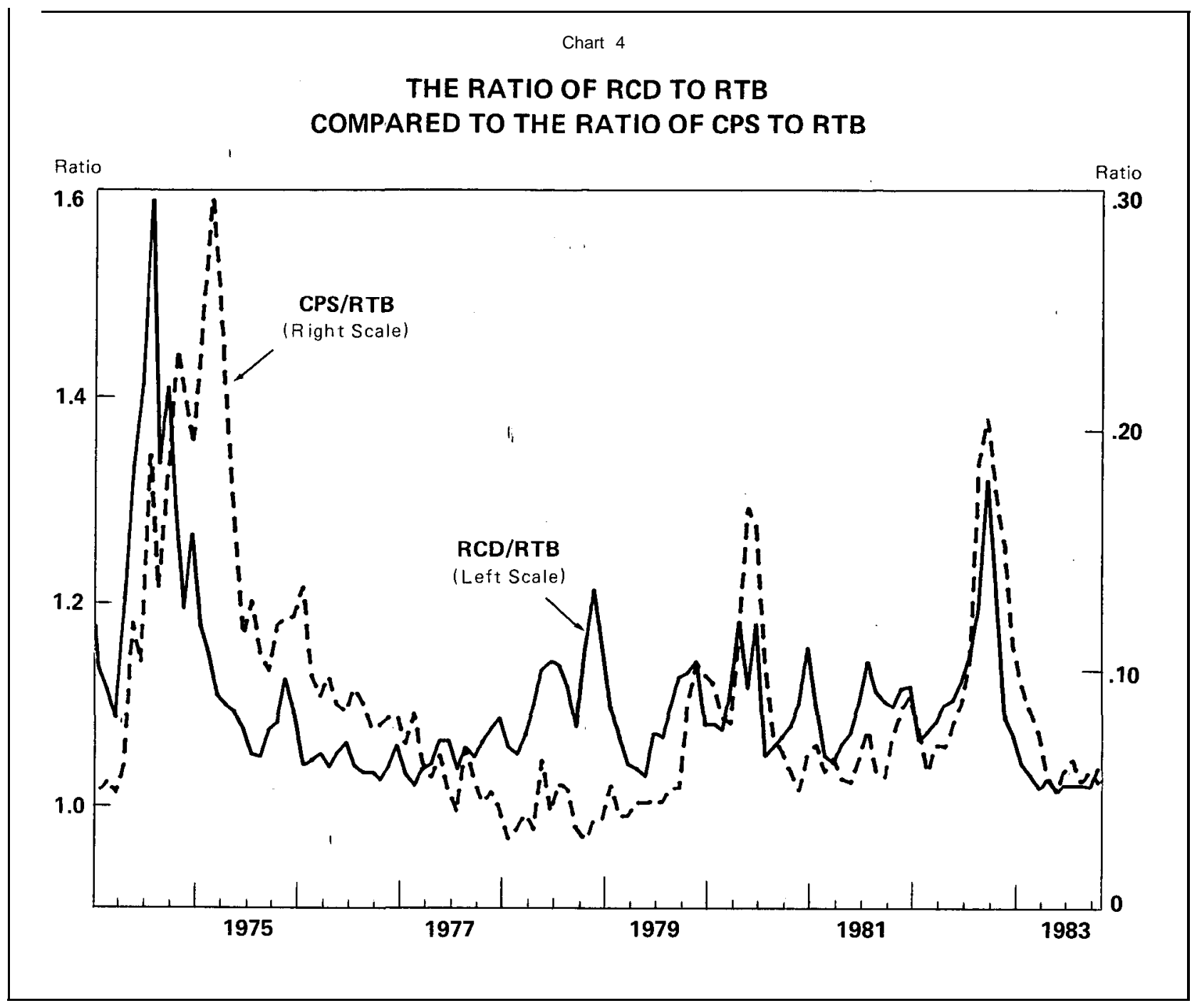

that the risk and tax model is superior to either the default-risk model or the tax model alone. ${ }^{12}$

\section{Heterogeneous Investor Model}

The tax and risk model assumes that all investors bear the same relative tax rates on private money securities and T-bills. As discussed above, however, there are substantial differences across investors with respect to the relative taxation of private versus T-bill interest income; that is, investors differ with respect to the tax rates they face.

A second source of investor heterogeneity involves various implicit returns that some investors receive

\footnotetext{
${ }^{12}$ In contrast, it is evident from Chart 4 that in the 1974-77 period the tax and risk model does a poor job of explaining the spread.
}

from holding T-bills-i.e., returns not measured by the stated T-bill yield. These implicit returns arise from various laws and regulations, many of which have changed over time. Banks, in particular, receive various implicit returns from holding Treasury bills. For example, banks (and other depository institutions) can use Treasury bills at full face value to satisfy pledging requirements against state and local and federal deposits. Also, Treasury bills improve the ratio of equity to risk assets, a measure bank regulators use to judge a bank's capital adequacy. Moreover, prior to the Monetary Control Act of 1980, nonmember banks in over half of the states had reserve requirements that could be satisfied at least partially-and in some cases totally-by holding unpledged Treasury bills. Finally, funds acquired by a bank that enters into a repurchase agreement are free 
of reserve requirements if the securities involved are obligations of the U. S. or federal agencies. ${ }^{13}$

Treasury bills also provide implicit returns by virtue of their preferred position in certain financial markets. They are accepted without question as collateral for margin purchases or short sales of securities. And they can be used to satisfy the initial margin requirements for many types of financial futures contracts, whereas private money market securities cannot be used for this purpose.

With different tax rates and implicit returns, investors will react differently to a particular RMMRTB spread. For example, even at a large RMMRTB spread and a very small default-risk premium, the demand for T-bills will be positive because investors with a high marginal state and local tax rate on private interest income and a zero-tax rate on T-bill interest income will find it advantageous to buy T-bills instead of CDs or commercial paper. As the spread falls, more and more investors with smaller differentials between the tax rates on interest income of private securities and T-bills will find it advantageous to buy T-bills. ${ }^{14} \mathrm{~A}$ similar conclusion holds for differential implicit returns. If these vary across investors, then a decline in the spread will induce investors receiving lower implicit returns to buy bills.

\footnotetext{
${ }^{13}$ These implicit returns are discussed in more detail in [7]. Pledging requirements are described in [1, 10, 14], state reserve requirements prior to the Monetary Control Act in [12], regulations on repurchase agreements in [17], and bank capital adequacy measures in [19].

${ }^{14}$ An assumption in this discussion is that the possible investment in Treasury bills by a particular investor is limited. The argument might be made that there are risk-free arbitrage opportunities that would provide incentives for investors to borrow funds in the bill (CD) market and lend them in the CD (bill) market. These opportunities generally are not present. because only the Treasury can issue T-bills and only the direct holder of T-bills receives the state and local tax exemption. For example, it might be argued that at large values of the spread, there is an opportunity for investors with equal tax rates on bill and private interest income to borrow bills at a rate slightly above the bill rate, sell them and invest the proceeds in private securities. However, investors that loan bills under this arrangement lose the tax exemption on $\mathrm{T}$-bill interest income; hence, they need to be paid at least RTB/(1-t) to be induced to loan their bills. This eliminates the arbitrage opportunity for the equal-tax rate investor.

Conversely, suppose the spread is zero; then there appears to exist arbitrage opportunities for investors with unequal tax rates on private and $\mathrm{T}$-bill interest income. These investors could issue private securities (deducting the interest paid from their-taxable income) and invest the funds in bills. However, as discussed in the text, investors with the highest tax rate on private versus bill interest income are individuals. They clearly are not able to, and do not, engage in this kind of activity. If individual investors pool their funds to buy bills, then they are in effect forming a financial intermediary to buy bills indirectly and they lose the tax exemption on T-bill
}

Consequently, with differing tax rates and implicit returns, the aggregate demand for T-bills-given some constant default-risk premium-decreases only gradually as the RMM-RTB spread rises. When the RMM-RTB spread is high relative to the default-risk premium, the aggregate demand for T-bills will be relatively low; as the RMM-RTB spread declines, the aggregate demand for T-bills will increase. When the spread falls to the level of the default-risk premium, the demand will be completely elastic as in the simple default-risk model.

Figure 3 illustrates the heterogeneous investor model. The figure shows that an increase in the level of interest rates can affect the RMM-RTB spread because of the tax effect. However, the effect of a rise in the level of rates on the spread depends on the relative supply of T-bills; the greater the relative supply of bills, the smaller the effect on the spread of a given increase in the level of rates.

Moreover, changes in the supply of T-bills can have a direct effect on the RMM-RTB spread. For instance, if the relative supply of T-bills falls, the RMM-RTB spread might rise, as a greater propor-

interest. This is precisely the situation of money market funds (see Section II of this article). However, in periods of very low values of the spread, there does appear to be arbitrage opportunities for large investors (i.e., banks) in states with high income tax rates who arenot 'subject' to excise or franchise taxes on T-bill interest income. In periods of small spreads, one might expect to see banks in these states issuing CDs to buy bills.

Figure 3

\section{HETEROGENEOUS INVESTOR MODEL}

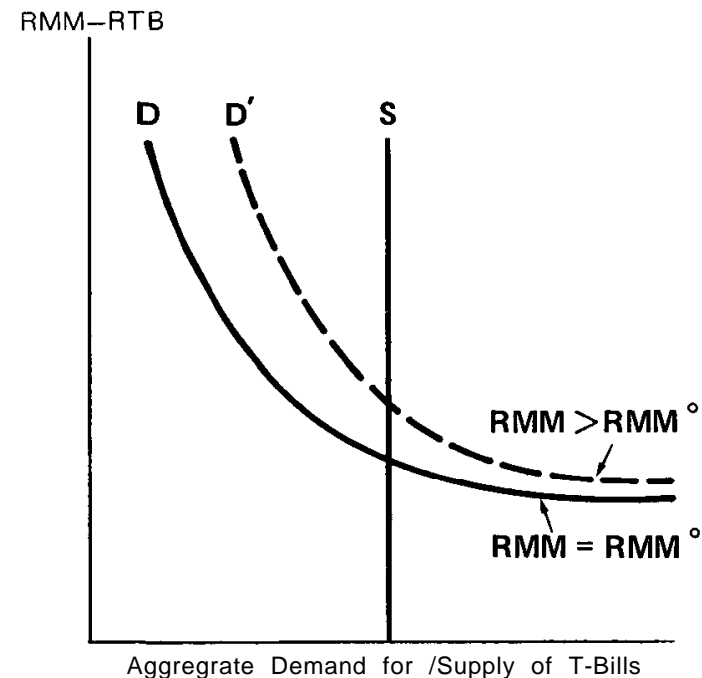


tion of T-bills are purchased by investors with a high marginal tax rate on private versus $\mathrm{T}$-bill interest income.

\section{II.}

\section{INVESTMENT IN T-BIUS BY INDIVIDUALS AND MMFS}

Additional evidence on the effect of differential taxation (of interest income on bills versus private securities) on the spread in the $1979-83$ period is contained in monthly data on T-bill investment by individuals and MMFs. As discussed earlier, individuals as a group have the largest differential between the tax rates paid on private versus T-bill interest income. At the other extreme are the shareholders of MMFs who are taxed equally on the interest of T-bills and private instruments.

No data is available on individual investment in T-bills. However, the percentage of bills awarded to noncompetitive bidders ${ }^{15}$ at weekly Treasury bill auctions is a widely used barometer of individual investment activity in the bill market. ${ }^{16}$ Chart 5

${ }^{15}$ Investors who purchase $\$ 1,000,000$ or less of bills at the weekly auction can make a "noncompetitive bid," whereby the investor agrees to pay the average price of accepted competitive bids. This amount was raised in 1983 from $\$ 500,000$

${ }^{16}$ See $[5]$.

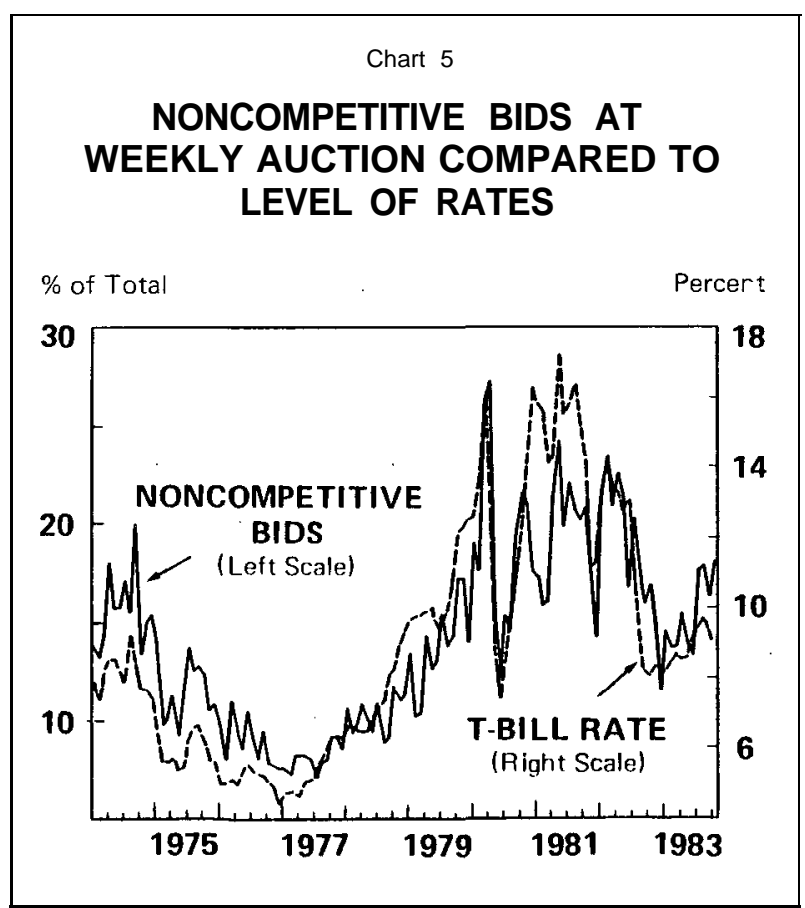

shows that the percent of noncompetitive bids at the weekly auction moves, closely with the level of interest rates. $^{17}$

Chart 6 compares the bill holdings of MMFs to the RMM-RTB spread. MMF investment in bills is negatively and strongly correlated to the spread. ${ }^{18}$ Hence, even though MMFs primarily buy bills indirectly for individual investors, their response to changes in the spread differs markedly from that of individual investors.

The pattern of investment in T-bills by individuals and MMFs can be explained by the different tax rates applicable to the two groups and, in addition, strongly suggests that taxes played a role in the behavior of the spread in the post-1978 period. The reasoning is as follows. As interest rates rise, at a given level of the before-tax RMM-RTB yield' spread, the after-tax yield spread falls for investors (individuals) taxed on private interest but not on T-bill interest, inducing them to increase their bill

\footnotetext{
${ }^{17}$ Based on Treasury Department data for 1986, 60 percent or more of the dollar volume of noncompetitive bids at the weekly Treasury bill auctions during that year (excluding noncompetitive bids made by Government accounts or the Federal Reserve) were made in the New York Federal Reserve District, which has by far the highest district-wide average state income tax rate.

${ }^{18}$ The correlation coefficient between the percent of MMF assets invested in bills and the spread over the period in Chart 6 is --.438 . In contrast, the correlation coefficient between noncompetitive bids and the spread is +.506 .
}

\section{Chart 6 \\ TREASURY BILLS AS A PERCENT OF TOTAL MMF ASSETS COMPARED TO RCD-RTB SPREAD}

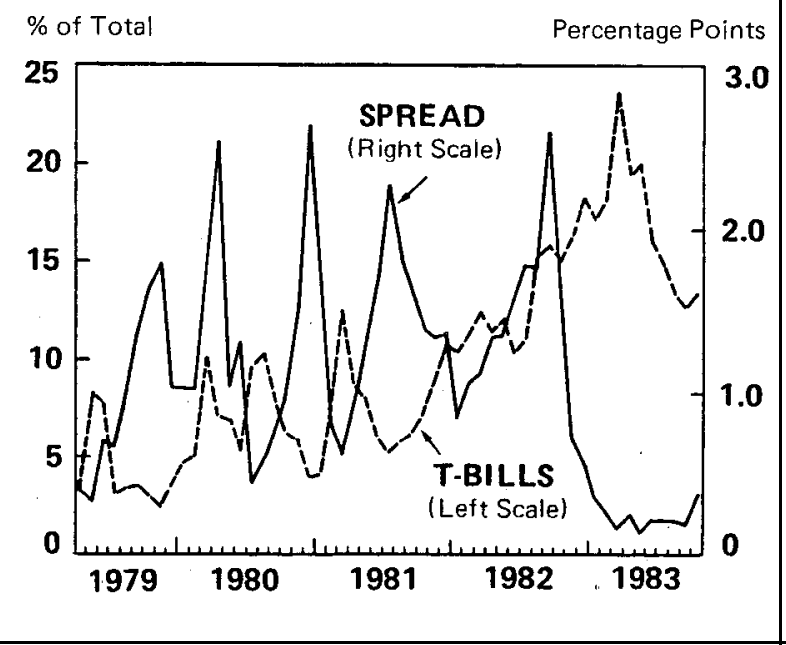


purchases. ${ }^{19}$ This puts downward pressure on the bill rate and increases the before-tax RMM-RTB yield spread. At the same time, the increase in the beforetax yield spread causes a comparable increase in the after-tax yield spread for investors (MMFs) who pay equal tax rates on $\mathrm{T}$-bill and private interest income. This rise in the after-tax yield spread induces them to decrease their purchase of bills. Hence, a rise in the level of interest rates is followed (1) by an increase in the holdings of bills by investors with unequal tax rates on $\mathrm{T}$-bill and private interest income, (2) by a rise in the RMM-RTB spread, and (3) by a decrease in the holdings of bills by investors with equal tax rates on the two types of interest income.

${ }^{19}$ It is relevant to this argument that following the growth of MMFs in 1978 and the introduction of MMCs in that year, the effect of taxes on the after-tax yields of these investments relative to the yields earned by direct investment in bills was well publicized. For instance! in March 1979 the Wall Street Journal published an article entitled "Where State and Local Taxes Hurt, Investors Can Earn More in Direct Purchases of Bills" [22]. See also $[3,5]$.

\section{III.}

\section{ESTIMATES OF THE SPREAD MODELS}

\section{Risk and Tax Models}

Regression estimates of the alternative models of the spread are presented in Table II. ${ }^{20}$ The spread between the medium-grade and prime-grade commercial paper rates (CPS) is used as a proxy for the default-risk premium on CDs, the assumption being that the true default-risk premium is linearly related to this spread.

The coefficient of CPS in the risk equation regres-

\footnotetext{
${ }^{20}$ The reported regressions follow the conventional procedure of using the risk-free rate (the $\mathrm{T}$-bill rate) as the right-hand side (independent) variable. Actually, the tax and risk model is an equilibrium relationship. Because of this, there is no a priori reason to use the Treasury bill as opposed to the $\mathrm{CD}$ rate as the right-hand side variable in the regression equations. The regressions were also estimated with the $C D$ rate as the right-hand side variable. The estimated coefficient of the interest rate variable in these regressions (reported in [8]) is somewhat higher; however, none of the conclusions reached in this section are different.
}

Table II

\section{RCD-RIB SPREAD REGRESSIONS}

\begin{tabular}{|c|c|c|c|c|c|c|c|c|c|c|c|}
\hline & & & & & 1979.1 & to $1983-6$ & & & & & \\
\hline & & Constant & CPS & RTB & $T B / L$ & $e^{-14(\mathrm{~TB} / \mathrm{L})_{\mathrm{RTB}}}$ & $\rho$ & D.W. & SER & $\bar{R}^{2}$ & $\begin{array}{l}\text { Implied } \\
\text { Tax Rate }\end{array}$ \\
\hline 1. & Risk Model & $\begin{array}{r}-.11 \\
(.45)\end{array}$ & $\begin{array}{c}1.35 \\
(5.46)\end{array}$ & & & & .52 & 1.94 & $\begin{array}{l}.376 \\
(.441)\end{array}$ & $\begin{array}{l}.642 \\
(.506)\end{array}$ & 0.0 \\
\hline 2. & Tax Model & $\begin{array}{l}-.27 \\
(.58)\end{array}$ & & $\begin{array}{l}.118 \\
(3.07)\end{array}$ & & & .63 & 1.76 & $\begin{array}{l}.423 \\
(.542)\end{array}$ & $\begin{array}{l}.546 \\
(.257)\end{array}$ & $10.6 \%$ \\
\hline 3. & Risk and Tax Model & $\begin{array}{c}-1.02 \\
(3.16)\end{array}$ & $\begin{array}{c}1.21 \\
(5.89)\end{array}$ & $\begin{array}{l}.090 \\
(3.57)\end{array}$ & & & .40 & 1.92 & $\begin{array}{c}.343 \\
(.376)\end{array}$ & $\begin{array}{c}.701 \\
(.643)\end{array}$ & $8.3 \%$ \\
\hline $4 a$. & $\begin{array}{l}\text { Heterogeneous } \\
\text { Investor Model }\end{array}$ & $\begin{array}{c}.12 \\
(.20)\end{array}$ & $\begin{array}{c}1.22 \\
(6.38)\end{array}$ & $\begin{array}{c}.082 \\
(3.46)\end{array}$ & $\begin{array}{r}-14.96 \\
(2.09)\end{array}$ & & .36 & 1.94 & $\begin{array}{l}.333 \\
(.357)\end{array}$ & $\begin{array}{c}.719 \\
(.677)\end{array}$ & $7.6 \%$ \\
\hline 4b. & $\begin{array}{l}\text { Heterogeneous } \\
\text { Investor Model }\end{array}$ & $\begin{array}{r}-1.04 \\
(3.70)\end{array}$ & $\begin{array}{l}1.21 \\
(6.39)\end{array}$ & & & $\begin{array}{l}.247 \\
(4.38)\end{array}$ & .37 & 1.94 & $\begin{array}{r}.329 \\
(.354)\end{array}$ & $\begin{array}{c}.725 \\
(.683)\end{array}$ & $\begin{array}{l}6.3 \text { to } \\
10.1 \%\end{array}$ \\
\hline
\end{tabular}

NOTES:

1. The Durbin-Watson statistics in the ordinary least-squares regressions were in the neighborhood of 1.0 to 1.2 , indicating the presence of autocorrelated residuals. Consequently, the equations were re-estimated using the Hildreth-Lu procedure to correct for first-order serial correlation. The values of $\rho$ in the transformed equation are shown in the table.

2. Numbers in parentheses under coefficients ore t-statistics. Numbers in parentheses under the SER and $\bar{R}^{2}$ are the values of the statistics for the comparable ordinary least-squares regressions. (The ordinary least-squares regression coefficients, reported in [8], were extremely close to those reported here.)

3. CPS is the spread between the one-month medium-grade and prime-grade commercial paper rates.

RTB is three-month bond-equivalent secondary market Treasury bill rate.

RCD is the three-month bond-equivalent prime negotiable $C D$ rate.

TB is the outstanding stock of Treasury bills less amount held by Federal Reserve.

$L$ is total liquid assets as defined by the Federal Reserve.

4. Treasury bills outstanding are from the Treasury Bulletin and the Monthly Statement of the Public Debt of the' United States, both published by the U. S. Treasury Department. All other data are from various publications of the Board of Governors of the Federal Reserve System. 
sion, equation 1 in Table II, has the correct sign and is highly significant. In the regression equation of the tax and risk model, equation 3, the coefficients of both the risk and tax variables have the correct signs and are highly significant. The overall fit of the estimated tax and risk model is considerably better than the simple risk model ${ }^{21}$ and the value of the autocorrelation coefficient, $\mathrm{p}$, is considerably lower.

These results support the conclusion that differential taxation of interest income on T-bills and private money securities was an important determinant of the RMM-RTB spread in the 1979-83 period. The tax rate implied by the coefficient of RTB in equation 3 is 8.3 percent, ${ }^{22}$ which is well within the range of state individual tax rates on interest income given in Table I. Hence, the magnitude of the interest rate coefficient is consistent with the tax explanation of the relationship between the level of rates and the spread in the post-1978 period.

\section{Heterogeneous Investor Model}

The implications of the heterogeneous investor model discussed in Section I were that (1) the RMM-RTB spread may be negatively related to the relative supply of T-bills and (2) the effects of the level of rates and the relative supply of T-bills on the spread may be interdependent; that is, the effect of an increase in the level of interest rates on the spread may depend on the supply of bills outstanding. ${ }^{23}$

The supply variable used in the heterogeneous investor model regressions is the ratio of T-bills outstanding net of Federal Reserve holdings (TB) to total liquid assets (L), a proxy for the overall size of the money market. ${ }^{24}$ Two regressions are reported

\footnotetext{
${ }^{21}$ This statement is especially true for the ordinary leastsquares summary statistics, which provide a more meaningful comparison across regressions since they do not depend on the value of the autocorrelation coefficient.

${ }^{22}$ The implied tax rate is calculated from equation 2 in the text as $c /(1+c)$ where $c$ is the coefficient of the Treasury bill rate.

${ }^{23}$ For previous evidence of supply effects on the spread see [16].

${ }^{24}$ The specific form of the supply variable used in these regressions is by necessity somewhat arbitrary. Regressions with alternative forms of the supply variable, reported in $[\mathrm{S}]$, did not alter the conclusion that the relative supply of Treasury bills affected the spread in the post1978 period. First, L, the denominator of the relative supply variable,, was replaced with two narrower measures: (1) T-bills plus large CDs plus commercial paper plus bankers acceptances and (2) T-bills plus large CDs. In both cases the t-statistic of the coefficient of the supply variable rose. Second, marketable U. S. government securities of foreign accounts held in custody at the Federal Reserve were netted out of the numerator of the relative supply variable. When this was done, the t-statistic of the coefficient of the supply variable rose.
}

in Table II. The first regression simply adds the relative supply variable to the tax and risk model. The variable's coefficient has the correct sign and is statistically significant. ${ }^{25}$ The magnitude of the coefficient implies that if the relative share of T-bills in total liquid assets rises by one percentage point, the RMM-RTB spread falls by 15 basis points. Treasury bills range from approximately 5.6 to 9.3 percent of total liquid assets over the period covered by the regressions; hence, the regression results imply that supply factors explain a relatively small part of the movement in the spread in that period.

The second regression reported in Table II uses a specification in which the effects of the interest rate and supply variables are interdependent :

$$
\text { Spread }=\mathbf{a}+\mathbf{b} \cdot \mathrm{CPS}+\mathbf{c} \cdot e^{\mathbf{a} \cdot \mathrm{TB} / \mathrm{L}} \cdot \mathrm{RTB},
$$

where $\mathrm{e}$ is the base of the natural logarithm. This specification also implies that the larger the relative share of bills to liquid assets (TB/L), the smaller the effect on the spread of further increases in the share, which should be the case if the aggregate demand for T-bills flattens out at low levels of RMMRTB, as argued earlier. This equation was estimated by experimenting with different values of $d$ and choosing the value of $\mathrm{d}$ for which the sum of squared residuals in the ordinary least-squares regression was lowest. The coefficient of the interest rate/supply variable is highly significant while the summary statistics of the regression are only slightly better than for the regression with the linear supply variable. The estimate of the tax rate implied by the coefficient of RTB ranges from 6.3 percent to 10.1 percent over the estimation period. ${ }^{26}$ While this specification yields results that are very close to the first one, it makes more sense a priori and for that reason should

\footnotetext{
${ }^{25}$ A reasonable question regarding this result is whether the coefficient of $\mathrm{TB} / \mathrm{L}$ is affected by simultaneous equations bias, i.e., whether a change in the RMM-RTB spread induces a response that alters the relative supply of T-bills outstanding. We do not think this is a serious problem because the movement in the $\mathrm{TB} / \mathrm{L}$ ratio is determined mainly by the movement in Treasury bills outstanding and the Treasury's supply of bills is clearly not responsive to the RMM-RTB spread. Admittedly, on a priori grounds it is possible that the supply of private securities by some agents may be marginally responsive to the spread. (Although see footnote 14 on this point.) For example, it might be argued that at large values of the spread, depository institutions that pay equal tax rates on bill and private interest income would sell bills and simultaneously run down their CDs outstanding. However, we are not aware of any evidence that the RMM-RTB spread is an important determinant of the aggregate supply of private short-term securities.

${ }^{26}$ This is calculated as $c^{*} / 1+c^{*}$ where $c^{*}$ is the coefficient of RTB in regression (4b) in Table II and is dependent on TB/L.
} 
fit the data better than the first specification in the future. Since the bill share variable TB/L should rise in coming years because of large budget deficits, this means that a rise in the level of rates should be associated with a smaller rise in the spread than in the $1979-83$ period.

\section{IV.}

\section{THE EFECT OF MMDAS ON THE SPREAD}

In mid-December 1982, all interest rate ceilings on short-term deposits with minimum denominations of $\$ 2500$ at depository institutions were removed. The "money market deposit accounts" (MMDAs) that resulted from this deregulation were very popular, reaching a level of $\$ 278$ billion by the end of February. A final question addressed here is whether the introduction of MMDAs decreased the demand for T-bills and thereby lowered the RMM-RTB spread.

Following the introduction of MMDAs, the RMM-RTB spread fell to extremely low levels; by March 1983 it had fallen to an average level of 16 basis points. However, the role played by MMDAs is difficult to isolate from other influences occurring at the time. Specifically, MMDAs were introduced at a time when there were major changes in the default-risk premium and tax rate variables that would also cause the spread to fall. Table III shows that the spread had already fallen sharply before the introduction of MMDAs in reaction to the decline in the default-risk premium and the lower level of interest rates. Also, as was shown in Chart 6, the demand for bills by individuals-as measured by noncompetitive bids at the weekly auction-had fallen sharply prior to the introduction of MMDAs in reaction to the decline in market interest rates.

Chart 7 shows the weekly data for noncompetitive bids around the time of the introduction of MMDAs. Noncompetitive bids dropped substantially the two weeks following the introduction of MMDAs. This occurred in a period of stable short-term interest rates, which indicates that initially MMDAs decreased the demand for bills by individuals. By the first weekly auction in January, however, noncompetitive bids had returned to their pre-MMDA level. Hence, there is little evidence from the noncompetitive bids data of a lasting effect of MMDAs on the demand for bills. To test for an effect on the RMM-RTB spread, a dummy variable was incorporated into the spread regression (equation $4 \mathrm{a}$ in Table II). This variable was set equal to 1 for the
Table III

\section{BEHAVIOR OF THE RCD-RIB SPREAD,} CPS AND RCD

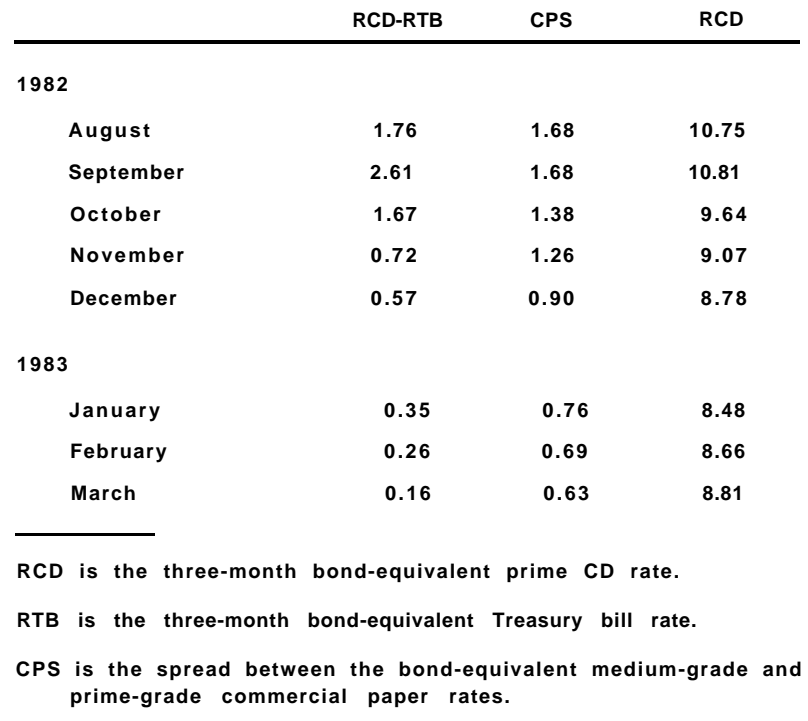

months beginning in December $1982 .^{27}$ The variable's coefficient was close to zero and not significant, which reinforces the evidence from the noncompetitive bids data.

\footnotetext{
${ }^{27}$ The dummy variable was given a value of 0.5 in December since MMDAs were introduced December 15.
}

Chart 7

\section{NONCOMPETITIVE BIDS AT WEEKLY TREASURY BILL AUCTION COMPARED TO THE CD RATE (November 1982 - February 1983)}

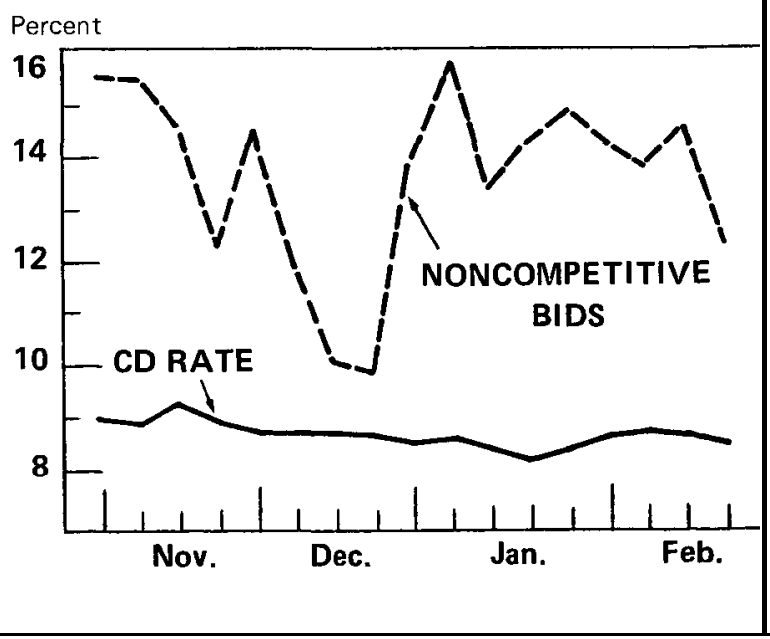




\section{V.}

\section{CONCLUSIONS}

The volatile behavior of the RMM-RTB spread over the post-1978 period can be fairly well explained by models that assume investors can choose freely between Treasury bills and private money market securities ${ }^{28}$ Variable default-risk premiums and differential taxation of interest income on bills and private securities were found to be the two major determinants of the spread in this period. A model of the spread that allowed for investors experiencing different tax rates and implicit returns was discussed. This model holds that the relative supply of bills can affect the spread. Regression results supported this contention, although the effect of the bill supply variable was small compared to the other two determinants of the spread.

\footnotetext{
${ }^{28}$ This raises the question of whether these models can explain the behavior of the spread in the pre-1978 period. Unfortunately, a key "variable used in this article--the commercial paper rate spread-is available only since 1974 and the only swing in the RMM-RTB spread in the 74-77 period occurred in 1974. (In contrast there were 5 major swings in the spread in the 1979-83 period.) However, the models discussed in this paper clearly do a poor job of explaining what happened to the spread in 1974. This conclusion is based on Charts 2, 3, 4 and footnotes 11 and 12. Chart 2 shows that the RMM-RTB spread fell sharply in the latter part of 1974 even though CPS stayed very high until the end of the 1974-75 recession. Chart 4 shows that the tax and risk model has the $\mathrm{s}$ a m e proble m.

The main implication of the simple tax model is similar to that of the disintermediation argument: both imply that the spread is positively related to the level of interest rates. However, the tax model clearly can not explain the extremely high levels of the RMM/RTB ratio, shown in Chart 3, in 1974. (Nor can the tax model explain values of the ratio persistently above 1.2 in earlier periods of disintermediation, such as 1969-70 and 1973.) Regressions for the 1974-77 period, reported in [8], reinforce the
} comments made here.

\section{References}

1. Advisory Commission on Intergovernmental Relations. The Impact of Increased Insurance on Public Deposits. Committee Print, prepared for the Committee on Banking and Urban Affairs, United States Senate. Washington, D. C.: U. S. Government Printing Office, 1977.

2. Understanding State and Local Cash Management. Washington, D. C.: U. S. Government Printing Office, 1977.

3. "Banks Pay Better Rates than the Treasury, but Dollar Results Now Are Less for Savers." Wall Street Journal, September 8, 1980, p. 52.

4. Board of Governors of the Federal Reserve System. State and Local Taxation of Banks, Part I, II, III, and IV. Committee Print, prepared for the Committee on Banking, Housing and Urban Affairs, United States Senate. Washington, D. C.: U. S. Government Printing Office, 1972.
5. "Buying a Treasury Bill Is More like Getting a Driver's License than a Piece of the Rock," Wall Street Journal, March 10, 1980, p. 44.

6. Commerce Clearing House, Inc. State Tax Handbook. Chicago: Commerce Clearing House, Inc., 1979.

7. Cook, Timothy Q. "Determinants of the Spread between Treasury Bill Rates and Private Sector Money Market Rates." Journal of Economics and Business (Spring-Summer 1981), pp. 177-87.

8. and Thomas A. Lawler. "The Behavior of the Spread Between Treasury Bill Rates and Private Money Market Rates Since 1978." Federal Reserve Bank of Richmond Working Paper 83-4.

9. Fama, Eugene. "Short-Term Interest Rates as Predictors of Inflation." American Economic Re. view (June 1975), pp. 269-82.

10. Federal Reserve System. Conference of Presidents. Ad Hoc Subcommittee on Full Insurance of Government Deposits. Final Report and Recommendations of the Ad Hoc Subcommittee on Full Insurance of Government Deposits. Federal Reserve Bank of Richmond, September 4, 1979. (Processed.)

11. Friedman, Benjamin M. "Interest Rate Expectations Versus Forward Rates: Evidence from an Expectations Survey." Journal of Finance 34 (September 1979), 965-73.

12. Gilbert, R. Alton, and Jean M. Lovati. "Bank Reserve Requirements and Their Enforcement: A Comparison Across States." Review, Federal Reserve Bank of St. Louis (March 1978), pp. 22-32.

13. Jones, David S., and V. Vance Roley. "Rational Expectations and the Expectations Model of the Term Structure : A Test Using Weekly Data." Journal of Monetary Economics (September 1983), pp. 453-65.

14. Haywood, C. F. The Pledging of Bank Assets: A Study of the Problem of Security for Public Deposits. Chicago: Association of Reserve City Bankers, 1967.

15. Karp, Daniel A. "State Taxation of Fifth District Banks." Economic Review, Federal Reserve Bank of Richmond (July/August 1974) pp. 19-23.

16. Lawler, Thomas A. "Seasonal Movements in ShortTerm Yield Spreads." Economic Review, Federal Reserve Bank of Richmond (July/August 1978), pp. 10-17.

17. Lucas, Charles M.; Marcos T. Jones; and Thorn B. Thurston. "Federal Funds and Repurchase Agreements." Quarterly Review, Federal Reserve Bank of New York (Summer 1977), pp. 33-48.

18. Mishkin, Frederic S. "Monetary Policy and ShortTerm Interest Rates: An Efficient MarketsRational Expectations Approach." Journal of Finance, (March 1982), pp. 63-72.

19. Summers, Bruce J. "Bank Capital Adequacy: Perspectives and Prospects." Economic Review, Federal Reserve Bank of Richmond (July/August 1977), pp. 3-8

20. Van Horne, James C. "Behavior of Default-Risk Premiums for Corporate Bonds and Commercial Paper." Journal of Business Research (December 1979), pp. 301-12.

21. Financial Market Rates and Flows. Englewood Cliffs, N. J. : Prentice-Hall, Inc., 1978.

22. "Where State and Local Taxes Hurt, Investors Can Earn More in Direct Purchases of T-Bills." Wall Street Journal, March 26, 1979, p. 32. 


\title{
EMPIRICAL COMPARISONS OF CREDIT AND MONETARY AGGREGATES USING VECTOR AUTOREGRESSIVE METHODS
}

\author{
Richard D. Porter and Edward K. O ffenbacher*
}

\section{INTRODUCTION}

Attention has been given recently to the issue of targeting a credit aggregate or to using information on a credit aggregate in addition to information on monetary aggregates in the implementation of monetary policy. In February 1983, the FOMC adopted an "associated range" of growth for total domestic nonfinancial debt (DNF) and decided "to evaluate debt expansion in judging responses to monetary aggregates." Much of the renewed interest in credit aggregates has been stimulated by Professor Benjamin Friedman.

Unquestionably one of the attributes of credit that has attracted Friedman and others is its velocity behavior. Chart 1 displays on a ratio scale the quarterly level of velocity (GNP/financial aggregate) from 1960 to 1982, for four aggregates: M1, M2, and two credit aggregates. The credit aggregates are debt owed by domestic nonfinancial sectors (DNF), and the private domestic nonfinancial sector's holding of currency, deposits and credit market instruments. The latter asset measure is the so-called "debt proxy" (DP) as coined by Henry Kaufman. Of the four aggregates, only the velocity for Ml has a decidedly upward trend over this period. Friedman has stressed that his preferred credit mea-

* Chief of the Econometric and Computer Applications Section, Division of Research and Statistics, Federal Reserve Board. and Economist, Bank of Israel, respectively. We wish to thank Robert Litterman of the Federal Reserve Bank of Minneapolis for useful comments and for assistance in using the RATS computer program. We also benefited from the comments of Robert Anderson. John Carlson, Don Kohn, Ken Kopecky, David Lindsey, Eileen Mauskopf, Ed McKelvey. Yash Mehra. Michael Prell, and John Wilson. We are grateful to David Wilcox and Anil Kashyap for distinguished research assistance. We wish to thank Mary Blackburn for expert typing of numerous drafts of this paper. The analyses and conclusions set forth are those of the authors and do not necessarily indicate concurrence by other members of the research staff, by the Board of Governors, or by the Reserve Banks; nor do they indicate concurrence by the staff or official representatives of the Bank of Israel.

${ }^{1}$ See Friedman [1981], [1982], [1983A], [1983B]. sure, DNF, as a percent of GNP has been about level, remaining within a few percentage points of its 1960 value of 144 percent. Chart 1, however, indicates that this ratio has moved up recently; in fact, it reached a level of 153 percent at the end of June $1983{ }^{2}$

It appears from Chart 1 that M1 velocity may be more variable than DNF, but the variability of velocity is not necessarily indicative of its predictability. Chart 2 presents errors in forecasting year over year growth rates in velocity, where the forecasts equal the average of all previous four quarter changes. ${ }^{3} \mathrm{On}$ the basis of this simple prediction scheme, it is not apparent that the velocity of M1 is more unpredict-

\footnotetext{
${ }^{2}$ Note that Friedman uses the reciprocal of velocity in his work. Thus, the recent decline in velocity represents an increase in the debt to income ratio.

${ }^{3}$ If $V_{t q}$ is the level of velocity in year $t$ and quarter $q$, the forecast of $100\left(\mathrm{~V}_{\mathrm{tq}} / \mathrm{V}_{\mathrm{t}-1, \mathrm{q}}-1\right)$ is made by averaging all past growth rates for the $\mathrm{q}^{\text {th }}$ quarter.
}

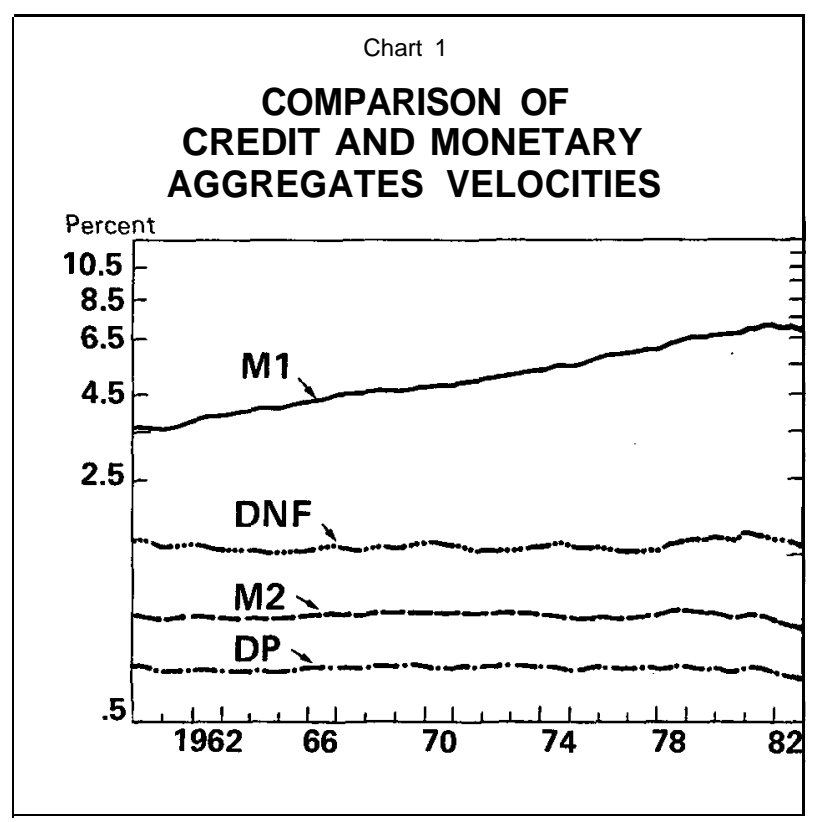




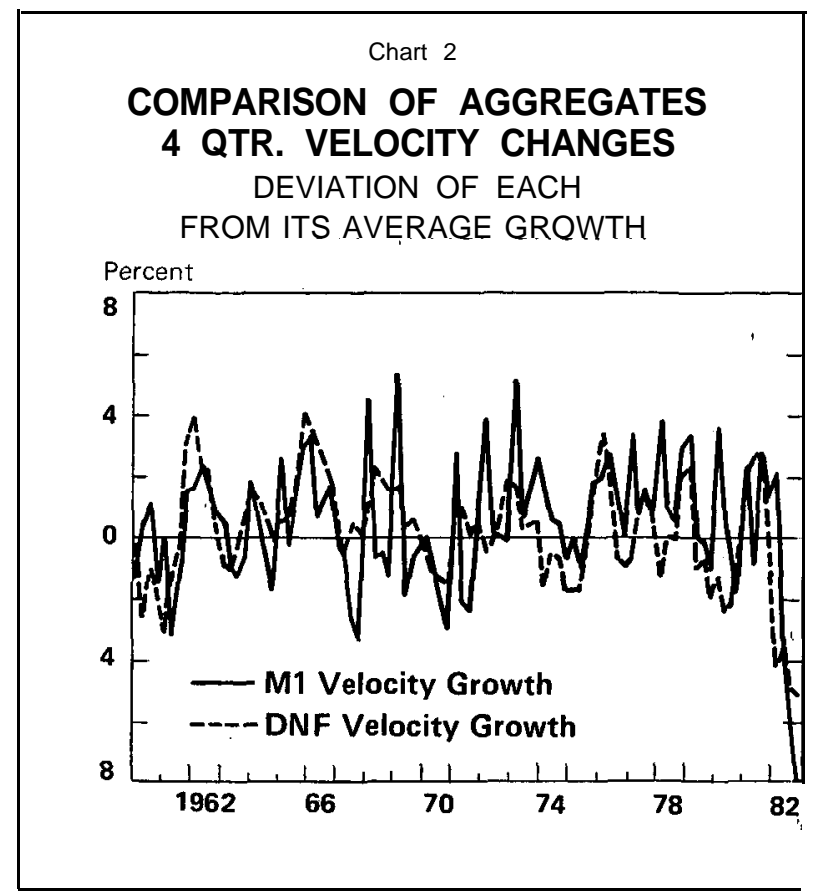

able than the velocity of DNF. In 1982, the history of neither aggregate predicted the sharp decline in velocity.

For monetary aggregates it is customary to make more detailed comparisons of velocity and its predictability from the vantage point of a theory of demand for the aggregate. For M1 or M2 there is a voluminous body of theory and empirical work to draw on. For credit aggregates, however, there is no established theory of aggregate debt holdings. ${ }^{4}$ In the absence of such an analytical framework, Friedman bases much of his empirical work on a form of statistical time series analysis, vector autoregression (VAR), which does not require a theoretical economic model. ${ }^{5}$ One conclusion that can be reasonably inferred from Friedman's work is that the DNF credit aggregate performs at least as well as any of the monetary aggregates in the VAR exercises.

This paper reports on some further work using the same VAR methodology. Our results do not

\footnotetext{
${ }^{4}$ Recent papers by Papademos and Modigliani [1983] and Gordon [1982] have made important contributions to the development of general equilibrium theory in which aggregate credit holdings can be analyzed.

${ }^{5}$ Within the economics profession the VAR model has been popularized in recent years by researchers at the University of Minnesota and the Federal Reserve Bank of Minneapolis, notably Robert Litterman [1982] and Professor Christopher Sims [1980A], [1980B]. While the primary uses of VAR have been in forecasting and data description, more recent applications, such as Sims [1982], have attempted to use this tool for policy analysis.
}

tend to support Friedman's policy recommendation that the FOMC establish a two target policy for monetary control consisting of M1 and DNF. Specifically, we show that Friedman's empirical results are quite sensitive to slight changes in either arbitrary or seemingly innocuous assumptions concerning data construction and the form of the VAR. Our results provide additional support to earlier warnings by others that policy implications drawn on the basis of VAR results should be scrutinized with great care. ${ }^{6}$

The remainder of this paper is organized as follows: Section II provides a critical review of the VAR methodology and Section III presents the empirical work. All of Section II need not be read in order to understand Section III. A concluding section provides an overall evaluation of this approach.

\section{EXPLANATION OF METHODOLOGY}

\section{Basic Regressions}

In its present form, vector autoregression is a tool for summarizing the relationships among a group of variables, e.g., economic time series; at various lags. A vector autoregression is not a single regression equation but a system of regressions with one equation for each variable in the system. Generally, the list of variables in the system is not based on prior' statistical testing. Given the variables selected, estimation of the autoregressive system consists of nothing more than a set of ordinary least squares regressions with the current value of each of the included variables being regressed on the lagged values of all the variables in the system. For example, if the vector autoregression includes only two variables, say M1 and GNP, and say, eight lags on each variable, then the vector autoregression consists of two regressions. In the "M1 equation," M1 would be regressed on eight lagged values of itself and eight lagged values of GNP ; in the "GNP regression" GNP would be regressed on the same set of sixteen explanatory variables. Note that in VAR models, current values of variables never appear, on the righthand side of any equation in the system. Thus, in a vector autoregression all current variables are treated as endogenous; all lagged variables are, of course, predetermined variables. The number of lagged values of each variable to he included on the righthand side of each regression must also be determined.

\footnotetext{
${ }^{6}$ See Zellner [1979], Gordon and King [1982], and Cooley and LeRoy [1982].
} 
While there exist statistical criteria to determine the maximal lag length, usually an arbitrary lag length is chosen for all variables in all equations.

These simple regressions constitute the only statistical estimation involved in vector autoregression. In fact, the simplicity of the estimation procedure and the ready availability of user-oriented computer programs that carry out such estimation are significant "advantages" of this approach. At the same time, however, one practical problem is the large number of parameters in the vector autoregression specification. When a constant is included in each equation, the number of parameters in each equation equals the number of variables in the system times the number of lags plus one. In the example cited above there are thus seventeen parameters to be estimated in each of the two equations. Accordingly, one must either limit the number of variables and/or lags in the system or else very long data series must be available.' Even if long series are available, the use of data from the remote past may be of dubious value when there is a strong suspicion of significant qualitative change in the economic environment, such as technological innovation or major changes in regulation or other policies.

\section{The Moving Average Representation and Impulse Response Function}

The regressions described in Part I are known as the autoregressive representation of the vector autoregression; the reason for this terminology being that the current values of all the variables in the system are regressed on their own lagged values (taken as a system). Another, perhaps more informative way of presenting the information contained in the vector autoregression, is the moving average representation $(M A R)$. This representation can be obtained directly from the autoregressive version as follows: The right-hand side of any regression equation contains a statistical disturbance term in addition to the explanatory variables. This disturbance reflects the fact that the sum of terms involving the explanatory variables (here only lagged values of all variables in the system) does not explain the dependent variable exactly at each observation. There will always be some discrepancy or disturbance. Since the explanatory variables in a vector autoregression include observations only prior to the current period, the disturbance is the only contributing factor to a given dependent

\footnotetext{
7 See Litterman [1982] and Doan, Litterman, and Sims [1983] for an approach which restricts the number of freely estimated parameters.
}

variable's value that is new to the current period. Accordingly, the current disturbance in the equation for a given variable is known as the innovation for that variable in the current period. A time series of such innovations exists for each variable in the vector autoregression. The moving average representation expresses current values of the dependent variables in terms of current and lagged values of the innovations in all variables of the system. In principle, an infinite number of lags is needed to obtain the entire moving average representation.

By a process of successive substitution we can derive the moving average representation from the autoregressive representation. An autoregressive system of order $\mathrm{n}$ and dimension $\mathrm{m}$ is a system of $\mathrm{m}$ variables containing lags from 1 to $n$. For example, for a second order system of dimension three, the autoregressive representation relates the current values of the dependent variables at time $t$, say $x_{t}, y_{t}$, $z_{t}$, as functions of a fixed number of their own lags, $x_{t-1}, x_{t-2}, y_{t-1}, y_{t-2}, z_{t-1}, z_{t-2}$. Each lagged value of each variable can be expressed as functions of still prior lagged values of all variables and the innovation that occurred at the given lag, e.g., $x_{t-1}$ depends on $\mathrm{x}_{\mathrm{t}-2}, \mathrm{x}_{\mathrm{t}-3}, \mathrm{y}_{\mathrm{t}-2}, \mathrm{y}_{\mathrm{t}-3}, \mathrm{z}_{\mathrm{t}-2}, \mathrm{z}_{\mathrm{t}-3}$ and the disturbance for $x_{t-1}$, call it $\epsilon_{t-1}^{x}$. The magnitudes $y_{t-1}$ and $z_{t-1}$ similarly depend on the same set of lagged variables and on $\epsilon_{\mathrm{t}-1}^{\mathrm{y}}$ and $\epsilon_{\mathrm{t}-1}^{\mathrm{z}}$, respectively. If we then repeat this calculation for the variables dated $t-2$, $\mathrm{t}-3, \mathrm{t}-4$, and so forth, we find that the innovations at these prior dates also enter the expression for $x_{t}$, $y_{t}$, and $z_{t}$. Such substitutions, when repeated into the infinite past, yield the moving average representation in which $x_{t}, y_{t}$, and $z_{t}$ depend on the current innovations, $\epsilon_{\mathrm{t}}^{\mathbf{x}}, \epsilon_{\mathrm{t}}^{\mathbf{y}}, \boldsymbol{\epsilon}_{\mathrm{t}}^{\boldsymbol{z}}$, the lagged one period innovations, $\epsilon_{\mathrm{t}-1}^{\mathrm{x}}, \epsilon_{\mathrm{t}-1}^{\mathrm{y}}, \epsilon_{\mathrm{t}-1}^{\mathrm{z}}$, the lagged two period innovations, $\boldsymbol{\epsilon}_{\mathrm{t}-2}^{\mathrm{x}}, \boldsymbol{\epsilon}_{\mathrm{t}-2}^{\mathbf{T}}, \boldsymbol{\epsilon}_{\mathrm{t}-2}^{\boldsymbol{z}}$, and so forth. In practice, of course, it is impossible to calculate exactly all of the coefficients in the infinite moving average representation; in most problems, however, coefficients for the recent past suffice. The moving average representation is used mainly to analyze the short- to medium-run effects on each variable of given innovations to each of the variables. For example, in a system with real GNP, the price level, a monetary aggregate and, possibly, other policy and nonpolicy variables one can estimate the effects of a shock (innovation) to money on real GNP and prices after, say, one quarter, two quarters, one year, two years, and so forth. Similarly, it is possible to calculate the effects of a shock to any given variable on the variable itself or on any other variable in the system. In 
other words, the moving average representation traces out over time the effect of any given innovation on any given variable. The entire time path of effects of one innovation on one variable is called an impulse response function. For example, one can talk of the responses of real GNP to a monetary shock as the impulse response function of real GNP with respect to money. The impulse response functions are, in principle, of interest to policymakers because they describe the effects and timing of policy variables on the variables of ultimate concern.

As a practical matter, however, there is one aspect of the determination of the impulse responses that may undermine their usefulness. While by construction the innovations in any series are serially uncorrelated, the innovations may be correlated contemporaneously. Therefore, it is not correct to interpret the effects of an innovation in a given variable, say, $\mathrm{x}$, as deriving solely from $\epsilon^{\mathrm{x}}$. Part of an innovation in $\mathrm{x}$ may be due to the contemporaneous influence of other innovations on the $\mathrm{x}$ innovation. Thus, for example, if the innovations in money and GNP are contemporaneously correlated, it is not correct to interpret the effect of an innovation in money on GNP as due solely to "exogenous" influences on the money supply, such as policy. Such contemporaneous correlation causes difficulty in interpreting a coefficient in the moving average representation as the effect of a given innovation on a given variable at a given lag. For example, recall that the coefficient in the moving average representation of the GNP on the first lagged innovation to money may be interpreted as the effect on GNP of last period's shock to money. However, if last period's shock to money is highly correlated with last period's GNP shock (contemporaneous "as of last period"), then it is not correct to attribute all of the money innovation to the independent effect of money. The contemporaneous correlation links the money and GNP innovations in a way that may prohibit further meaningful decomposition.

There is a way around this problem but it is quite possible that the problems involved in implementing the solution are as serious as the original problem. Briefly, it is possible to apply certain mathematical transformations to the correlation matrix of the innovations to generate a new set of innovations that are not contemporaneously correlated. However, this transformation is not unique, i.e., it can be implemented in several ways depending on how the vari- ables in the system are ordered. ${ }^{8}$ Thus, the transformation may generate qualitatively different impulse response patterns depending on the ordering of the variables. This problem would not he serious if the untransformed innovations did not happen to be highly correlated in the first place or if the answers to questions of major concern were not sensitive to the ordering of variables in the transformation. Unfortunately the reported results show that for some systems estimated by Friedman neither condition holds. In particular, in the systems that include nominal GNP and either a monetary or a credit aggregate the innovations are sufficiently correlated that the ordering of variables in the transformation substantially affects the results of the transformation. Such systems do not yield unequivocal conclusions.

\section{Variance Decompositions}

The most important question in comparing money and credit aggregates is to determine whether movement in the financial aggregate exerts an independent influence on the broader policy objectives. The strength of this influence is also critical.

An impulse response function describes the effect of an innovation in a given variable on the movement of the level of the same or another variable in the system. For example, the impulse response function of GNP with respect to money describes how the level of GNP changes over time in response to a shock to money. The set of impulse response functions for an entire system can be viewed as a decomposition of the levels of the variables in the system

\footnotetext{
${ }^{8}$ The terms "ordered" and "ordering" refer to the order of the variables in setting up the transformation. The only aspect of the transformation that is truly germane to this exposition is the fact that the ordering is arbitrary but conclusions may sometimes differ depending on the ordering of variables that is chosen. The intuition behind the transformation can be explained quite easily. Recall that the purpose of the transformation is to allocate contemporaneous correlation of the innovations. The variables are ordered in some fashion, say, first variable, second variable, and so forth. The first variable's innovations are assumed to be independent, i.e., all correlation between this innovation series and other innovation series affects only the other innovations. The second variable's innovations are assumed to be independent except for the part correlated with the first variable's innovations. The transformation subtracts from the second variable's innovations the part attributable to the first variable and only that part. The third variable's innovations are assumed to be independent except for the parts due to the first and second variable's innovations which are subtracted out. In general, the transformation eliminates the correlation from any given innovation series and those series that appear prior to it in the particular ordering. This sequential process of eliminating correlated parts of the innovation series results in a set of transformed innovations that are not contemporaneously correlated.
} 


\begin{tabular}{|c|c|c|c|c|c|c|c|c|}
\hline \multirow{2}{*}{$\begin{array}{l}\text { Dependent } \\
\text { Variable }\end{array}$} & \multicolumn{8}{|c|}{ Coefficients on Lagged NGNP } \\
\hline & $i$ & 2 & 3 & 4 & 5 & 6 & 7 & 8 \\
\hline M1 & $\begin{array}{r}-.07 \\
(-1.1)\end{array}$ & $\begin{array}{c}.02 \\
(.3)\end{array}$ & $\begin{array}{r}-.15 \\
(-1.7)\end{array}$ & $\begin{array}{c}.16 \\
(1.7)\end{array}$ & $\begin{array}{l}-.02 \\
(-.2)\end{array}$ & $\begin{array}{r}-.22 \\
(-2.3)\end{array}$ & $\begin{array}{r}.45 \\
(4.7)\end{array}$ & $\begin{array}{r}-.19 \\
(-2.8)\end{array}$ \\
\hline NGNP & $\begin{array}{r}.99 \\
(8.9)\end{array}$ & $\begin{array}{l}-.12 \\
(-.7)\end{array}$ & $\begin{array}{c}.77 \\
(.5)\end{array}$ & $\begin{array}{l}-.08 \\
(-.5)\end{array}$ & $\begin{array}{l}-.04 \\
(-.2)\end{array}$ & $\begin{array}{l}.03 \\
(.2)\end{array}$ & $\begin{array}{r}.21 \\
(1.3)\end{array}$ & $\begin{array}{r}-.19 \\
(-1.7)\end{array}$ \\
\hline DNF EOQ & $\begin{array}{c}.04 \\
(1.3)\end{array}$ & $\begin{array}{r}-.05 \\
(-1.1)\end{array}$ & $\begin{array}{l}-.04 \\
(-.8)\end{array}$ & $\begin{array}{r}-.00 \\
(.04)\end{array}$ & $\begin{array}{l}-.01 \\
(-.3)\end{array}$ & $\begin{array}{l}-.01 \\
(-.1)\end{array}$ & $\begin{array}{l}-.06 \\
(1.3)\end{array}$ & $\begin{array}{r}-.03 \\
(.8)\end{array}$ \\
\hline NGNP & $\begin{array}{r}1.07 \\
(9.7)\end{array}$ & $\begin{array}{r}-.29 \\
(-1.8)\end{array}$ & $\begin{array}{r}.34 \\
(.2)\end{array}$ & $\begin{array}{l}-.11 \\
(-.7)\end{array}$ & $\begin{array}{l}.04 \\
(.3)\end{array}$ & $\begin{array}{l}.14 \\
(.9)\end{array}$ & $\begin{array}{l}.22 \\
(.1)\end{array}$ & $\begin{array}{r}.35 \\
(.3)\end{array}$ \\
\hline DNF QA & $\begin{array}{r}.04 \\
(2.2)\end{array}$ & $\begin{array}{r}-.06 \\
(-2.3)\end{array}$ & $\begin{array}{c}.00 \\
(.01)\end{array}$ & $\begin{array}{r}-.02 \\
(-1.0)\end{array}$ & $\begin{array}{c}.01 \\
(.6)\end{array}$ & $\begin{array}{l}-.02 \\
(-.6)\end{array}$ & $\begin{array}{r}.03 \\
(1.4)\end{array}$ & $\begin{array}{r}.02 \\
(1.1)\end{array}$ \\
\hline NGNP & $\begin{array}{r}1.09 \\
(10.2)\end{array}$ & $\begin{array}{r}-.28 \\
(-1.9)\end{array}$ & $\begin{array}{c}-.01 \\
(-.08)\end{array}$ & $\begin{array}{l}-.09 \\
(-.0)\end{array}$ & $\begin{array}{c}.01 \\
(.04)\end{array}$ & $\begin{array}{r}.18 \\
(1.2)\end{array}$ & $\begin{array}{l}-.02 \\
(-.1)\end{array}$ & $\begin{array}{c}.08 \\
(.7)\end{array}$ \\
\hline
\end{tabular}

\begin{tabular}{|c|c|c|c|c|c|c|c|}
\hline \multicolumn{8}{|c|}{ Coefficients on Lagged Financial Aggregate } \\
\hline 1 & 2 & 3 & 4 & 5 & 6 & 7 & 8 \\
\hline $\mathrm{T} .21$ & -.21 & .15 & -.26 & .49 & -.17 & -.41 & .21 \\
\hline (10.9) & $(-1.2)$ & (.9) & $(-1.7)$ & (3.2) & $(-1.0)$ & $(-2.2)$ & $(1.7)$ \\
\hline .58 & .01 & -.61 & .15 & -.10 & -.02 & -.17 & .19 \\
\hline (3.1) & (.02) & $(-2.3)$ & (.6) & $(-.03)$ & $(-.06)$ & $(-.6)$ & (.9) \\
\hline 1.3 & .3 & -.2 & -.09 & .3 & -.3 & -.1 & .1 \\
\hline (11.8) & $(.02)$ & $(-1.3)$ & $(-.6)$ & (2.1) & $(-1.9)$ & $(-.9)$ & (1.3) \\
\hline .37 & .65 & -1.0 & .36 & -.30 & .20 & -.12 & -.10 \\
\hline$(1.0)$ & (1.1) & $(-1.9)$ & (.7) & $(-.6)$ & (.4) & $(-.2)$ & $(-.3)$ \\
\hline 2.02 & -1.52 & .95 & -.76 & .79 & -.67 & .09 & .09 \\
\hline (19.1) & $(-6.5)$ & (3.4) & $(-2.7)$ & (2.9) & $(-2.5)$ & (.4) & $(1,0\}$ \\
\hline .52 & .81 & -2.34 & 2.56 & -2.87 & 3.39 & -3.31 & T.27 \\
\hline (.8) & (.6) & $(-1.4)$ & $(1.5)$ & $(-1.7)$ & (2.0) & $(-2.4)$ & (2.2) \\
\hline
\end{tabular}

into components due to the various shocks to these variables. It is also possible to decompose variation in the system into components due to variation in the shocks. This decomposition is generally done in terms of the forecast error variance. The value of a given variable $\mathrm{k}$ periods into the future will be based on all current and past innovations and on innovations that are yet to be realized in the $\mathrm{k}$ periods yet to occur. The information available today (time $t$ ) includes the actual values of current and past innovations while the future innovations are random variables whose expected values are zero. ${ }^{9}$ Consider now a $k$ period ahead forecast of the variable $y_{t+k}$. In order to obtain the forecast of $y_{T+K}$ write the moving average representation of $y_{t+k}$ including all innovations up to $\mathrm{t}+\mathrm{k}$, substitute in the values for innovations known at time $t$, and set to zero values of the innovations which may occur between $t+1$ and $\mathrm{t}+\mathrm{k}$.

Now consider the variance of the forecast error. Since at time $\mathrm{t}$ all innovations dated $\mathrm{t}$ and earlier are known by assumption, these innovations contribute nothing to the forecast error. Instead, the forecast error will be due to the existence of nonzero innovations to $\mathrm{y}_{\mathrm{t}+\mathrm{k}}$ which may occur between $\mathrm{t}+1$ and $\mathrm{t}+\mathrm{k}$. If we use the variation of innovations in the past as the estimate for the variation of future innovations, it is possible to get an estimate of the forecast error variance. The word "variation" in this context refers not only to the variance of each innovation series but to the contemporaneous covariances among all pairs of innovations. As with the impulse response function, it is precisely this covari-

\footnotetext{
${ }^{9}$ Deterministic time trends may also be incorporated into the analysis.
}

ation that generates problems for interpreting the decomposition of the forecast error variance.

We have seen that the forecast error variance for a given variable is equal to a sum of terms in the variances and covariances of all the innovation series. The variance decomposition (VARD) presents a summary of this information by listing the fraction of the overall forecast error variance accounted for by each of the types of innovations. This variance allocation, or variance accounting, can be done for the forecast error of each variable for any forecast horizon. In this way, one can analyze the way in which the variances of each variable's innovations influences the movements (i.e., the variation) in each of the variables in the system. In principle, the variance decomposition contains very important information because it shows which variables have relatively sizable independent influence on other variables in the system.

The fly in the ointment is the same problem as the one mentioned in the previous discussion, of the impulse response function: alternative orderings of the variables may imply substantially different allocations of explanatory power. Thus, the importance of a given variable in terms of the extent to which its innovations influence other variables may depend critically on the (arbitrary) ordering that is chosen.

\section{EMPIRICAL RESULTS}

\section{Selected VAR Estimates}

We follow Friedman's specification in assuming that the endogenous variables in the VAR specification enter as natural logarithms and that the equation contains a constant, a linear time trend, and 


\begin{tabular}{|c|c|c|c|c|c|c|}
\hline Constant & Trend & $F_{\text {financial }}$ & ${ }_{\text {GNP }}$ & $\overrightarrow{\mathrm{R}}^{2}$ & $Q(30)$ & $\begin{array}{l}\text { Residual } \\
\text { Standard } \\
\text { Deviation }\end{array}$ \\
\hline $\begin{array}{r}.06 \\
(1.2)\end{array}$ & ${ }_{(1.2)}^{.00035}$ & 180.7 & 5.2 & .9997 & 14.29 & .0052 \\
\hline $\begin{array}{r}.17 \\
(2.1)\end{array}$ & $\begin{array}{l}.0010 \\
(2.1)\end{array}$ & 3.44 & 47.5 & .9998 & 17.97 & .0088 \\
\hline $\begin{array}{r}.05 \\
(1.8)\end{array}$ & $\begin{array}{l}.00019 \\
(2.3)\end{array}$ & 357.9 & 2.86 & .9999 & 31.73 & .0030 \\
\hline $\begin{array}{r}.15 \\
(1.7)\end{array}$ & $\begin{array}{l}.00050 \\
(1.8)\end{array}$ & 2.31 & 38.6 & .9998 & 23.25 & .0091 \\
\hline $\begin{array}{r}.02 \\
(1.6)\end{array}$ & $\begin{array}{l}.00010 \\
(2.2)\end{array}$ & 1243.7 & 3.91 & .9999 & 27.61 & .0014 \\
\hline $\begin{array}{r}.13 \\
(1.5)\end{array}$ & $\begin{array}{l}.00048 \\
(1.7)\end{array}$ & 2.88 & 40.8 & .9998 & 20.70 & .0089 \\
\hline
\end{tabular}

eight lags on each (endogenous) variable in the system. ${ }^{10}$ In this paper, we also used the longest sample period available from 1954:Q2 until 1982: Q4." Four different VAR systems were estimated: a two-variable system consisting of a financial aggregate and nominal GNP, (Table I); a three-variable system consisting of a financial aggregate, real GNP and the GNP deflator and two systems containing a short-term interest rate in addition to financial and real sector variables. In the latter category are the estimates from a trivariate model (Table II) for a financial aggregate, nominal GNP and the commercial paper rate and a four-variable system consisting of a financial aggregate, real GNP, the GNP deflator and the commercial paper rate. ${ }^{2}$ (Appendix A lists the definitions for the abbreviations used throughout this section.) The following notation is used in the tables: estimated t-ratios are listed in parentheses beneath the regression coefficients; $Q(30)$ is the Box-Pierce Chi-square statistic with 30 degrees of freedom to test the hypothesis that the residuals from each equation are serially uncorrelated; the symbol

${ }^{10}$ See Friedman [1981] and [1983B]. We also examined specifications which only contained four lags, see footnote 17.

"The results do not appear to be sensitive to the sample period chosen. See Offenbacher, McKelvey, and Porter [1982] for results from a shorter sample period from 1959 to 1980

${ }^{12}$ In order to conserve space, VAR estimates for the four-variable model and the three-variable model without interest rates are not shown. The results for M2 were also eliminated from Tables I and II to trim their size. The inferences drawn for the debt proxy are similar in spirit to the ones drawn for DNF, so for the sake of brevity we only report those for DNF in this paper. The interested reader may consult Offenbacher and Porter [1983] for a discussion of the empirical results for the debt proxy, as well as the M2 results that were not shown in the two tables.
$\mathrm{F}$, (for $\mathrm{x}=$ financial, NGNP, RCP), represents the F-statistic which tests the hypothesis that the coefficients on all lagged x's are simultaneously equal to zero; it is distributed with 8 and 97 degrees of freedom in the bivariate models and with 8 and 89 degrees of freedom in the trivariate model.

In the bivariate system (Table II) all variables are significant at the five percent level. In the trivariate system containing an interest rate (Table III, M1 is significant at the ten percent level in the interest rate and nominal GNP equations; DNF, on the other hand, is insignificant at this level in both of these equations.

\section{Impulse Response Functions}

Recall that the impulse response function for GNP with respect to a money shock describes the response over time of GNP to an innovation or a shock to money in a given period. Charts 3 and 4 depict the impulse responses of the natural logarithms of the inverse of velocity, $\ln (\mathrm{F} / \mathrm{NGNP})$, to a one percent shock in the financial aggregate, F. For systems that include real GNP and the GNP deflator instead of nominal GNP, the response of nominal GNP to a given shock is obtained by summing the responses of real GNP and the GNP deflator. In general, one would expect an initial fall in velocity in response to a positive shock to the aggregate because nominal GNP responds to the financial stimulus with a lag. As income begins to respond to the stimulus and the effect of the shock on financial assets dissipates, velocity will gradually rise. The impulse response function that emerges typically has a damped, sinusoidal shape.

According to Friedman, the purpose of looking at these impulse response functions is to assess the stability of the relationship between nominal GNP and each financial aggregate. If, as expected, the response pattern damps out and is smooth, then the relationship is considered to be stable. Presumably a relatively stable relationship is conducive to more effective monetary policy. ${ }^{13,14}$ ${ }^{13}$ Analytically, one can assess the stability, by looking at
the eigenvalues of the first-order "stacked" representation
of the system. An inspection of these eigenvalues reveals
that all of the estimated systems are stable. It follows
from this result that the associated impulse response
functions are stable and will eventually converge to zero.
${ }^{14}$ Stability is not used here in the statistical sense to
denote stability of the coefficients over different time
periods. Friedman does not discuss the implications of
relevant economic theory for the expected pattern of the
impulse response function of ln(F/NGNP). For credit
(footnote continued on page 22) 
Table II

\begin{tabular}{|c|c|c|c|c|c|c|c|c|c|c|c|c|c|c|c|c|}
\hline \multirow{2}{*}{$\begin{array}{c}\text { Dependent } \\
\text { Yariable }\end{array}$} & \multicolumn{8}{|c|}{ Coefficients on Lagged NGNP } & \multicolumn{8}{|c|}{ Coelficients on Laggad Finaneial Aggregate } \\
\hline & 1 & 2 & 3 & 4 & 5 & 6 & 7 & 8 & 1 & 2 & 3 & 4 & 5 & 6 & 7 & $\mathbf{8}$ \\
\hline$M]$ & $\begin{array}{l}-.02 \\
(-.2)\end{array}$ & $\begin{array}{l}.02 \\
(.2)\end{array}$ & $\begin{array}{r}-.18 \\
(-2.1)\end{array}$ & $\begin{array}{r}.13 \\
(1.6)\end{array}$ & $\begin{array}{l}-.01 \\
(-.1)\end{array}$ & $\begin{array}{r}-.18 \\
(-2.2)\end{array}$ & $\begin{array}{r}.39 \\
(4.7)\end{array}$ & $\begin{array}{r}-.10 \\
(-1.5)\end{array}$ & $\begin{array}{l}1.05 \\
(9.2)\end{array}$ & $\begin{array}{r}-.01 \\
(-0.0)\end{array}$ & $\begin{array}{l}.03 \\
(.2)\end{array}$ & $\begin{array}{r}-.18 \\
(-1.2)\end{array}$ & $\begin{array}{r}.45 \\
\text { (2.8) }\end{array}$ & $\begin{array}{r}-.21 \\
(-1.2)\end{array}$ & $\begin{array}{l}-.15 \\
(-.8)\end{array}$ & $\begin{array}{l}-.03 \\
(-.2)\end{array}$ \\
\hline NGNP & $\begin{array}{r}.91 \\
(7.7)\end{array}$ & $\begin{array}{l}-.11 \\
(-.7)\end{array}$ & $\begin{array}{l}.06 \\
(.4)\end{array}$ & $\begin{array}{l}-.07 \\
(-.4)\end{array}$ & $\begin{array}{l}-.09 \\
(-.6)\end{array}$ & $\begin{array}{l}.09 \\
(.6)\end{array}$ & $\begin{array}{r}.17 \\
(1.1)\end{array}$ & $\begin{array}{l}-.04 \\
(-.3)\end{array}$ & $\begin{array}{r}.35 \\
(1.7)\end{array}$ & $\begin{array}{l}.15 \\
(.5)\end{array}$ & $\begin{array}{r}-.59 \\
(-2.1)\end{array}$ & $\begin{array}{l}.20 \\
(.7)\end{array}$ & $\begin{array}{l}.16 \\
(.5)\end{array}$ & $\begin{array}{r}-.39 \\
(-1.1)\end{array}$ & $\begin{array}{l}.20 \\
(.6)\end{array}$ & $\begin{array}{r}-.02 \\
(-.1)\end{array}$ \\
\hline RCP & $\begin{array}{c}3.3 \\
(2.5)\end{array}$ & $\begin{array}{l}-.92 \\
(-.5)\end{array}$ & $\begin{array}{l}-1.29 \\
(-.7)\end{array}$ & $\begin{array}{l}-.12 \\
(-.1)\end{array}$ & $\begin{array}{l}-.50 \\
(-.3)\end{array}$ & $\begin{array}{l}-1.08 \\
(-.6)\end{array}$ & $\begin{array}{l}1.10 \\
(.6)\end{array}$ & $\begin{array}{r}.27 \\
(.2)\end{array}$ & $\begin{array}{r}3.55 \\
(1.5)\end{array}$ & $\begin{array}{l}-1.33 \\
(-.4)\end{array}$ & $\begin{array}{c}2.08 \\
(.7)\end{array}$ & $\begin{array}{l}-10.1 \\
(-3.3)\end{array}$ & $\begin{array}{c}7.8 \\
(2.4)\end{array}$ & $\begin{array}{l}1.1 \\
(.3)\end{array}$ & $\begin{array}{c}-3.9 \\
(-1.0)\end{array}$ & $\begin{array}{l}.20 \\
\text { (.1) }\end{array}$ \\
\hline DNF EOO & $\begin{array}{l}-.00 \\
(-.1)\end{array}$ & $\begin{array}{l}-.02 \\
(-.5)\end{array}$ & $\begin{array}{l}.02 \\
(.5)\end{array}$ & $\begin{array}{l}.01 \\
(.2)\end{array}$ & $\begin{array}{l}-.03 \\
(-.6)\end{array}$ & $\begin{array}{l}-.04 \\
(-.9)\end{array}$ & $\begin{array}{r}.08 \\
(1.8)\end{array}$ & $\begin{array}{r}.04 \\
(1.1)\end{array}$ & $\begin{array}{c}1.03 \\
(9.7)\end{array}$ & $\begin{array}{c}.42 \\
(.3)\end{array}$ & $\begin{array}{r}-.09 \\
(-.0)\end{array}$ & $\begin{array}{l}-.08 \\
(-.0)\end{array}$ & $\begin{array}{r}.34 \\
(2.5)\end{array}$ & $\begin{array}{c}-.28 \\
(-.20)\end{array}$ & $\begin{array}{r}-.19 \\
(-1.3)\end{array}$ & $\begin{array}{r}.16 \\
(1.8)\end{array}$ \\
\hline NGNP & $\begin{array}{r}1.00 \\
(8.6)\end{array}$ & $\begin{array}{r}-.16 \\
(-1.0)\end{array}$ & $\begin{array}{r}.09 \\
(.6)\end{array}$ & $\begin{array}{l}-.14 \\
(-.9)\end{array}$ & $\begin{array}{l}-.15 \\
(-.9)\end{array}$ & $\begin{array}{l}.11 \\
(.7)\end{array}$ & $\begin{array}{r}.07 \\
(.5)\end{array}$ & $\begin{array}{l}.06 \\
(.4)\end{array}$ & $\begin{array}{l}-.09 \\
(-.2)\end{array}$ & $\begin{array}{r}.67 \\
(1.2)\end{array}$ & $\begin{array}{r}-.85 \\
(-1.6)\end{array}$ & $\begin{array}{r}.45 \\
(.9)\end{array}$ & $\begin{array}{l}-.46 \\
(-.9)\end{array}$ & $\begin{array}{l}.34 \\
(.6)\end{array}$ & $\begin{array}{r}.01 \\
(0.0)\end{array}$ & $\begin{array}{l}-.01 \\
(-.4)\end{array}$ \\
\hline RCP & $\begin{array}{c}5.56 \\
(4.3)\end{array}$ & $\begin{array}{c}-3.84 \\
(-2.1)\end{array}$ & $\begin{array}{c}0.0 \\
(0.0)\end{array}$ & $\begin{array}{l}-1.83 \\
(-1.0)\end{array}$ & $\begin{array}{l}1.16 \\
(.7)\end{array}$ & $\begin{array}{r}-1.89 \\
(-1.1)\end{array}$ & $\begin{array}{r}.37 \\
(.2)\end{array}$ & $\begin{array}{l}.21 \\
(.1)\end{array}$ & $\begin{array}{l}-1.14 \\
(-.3)\end{array}$ & $\begin{array}{l}7.15 \\
(1.1)\end{array}$ & $\begin{array}{l}-10.1 \\
(-1.7)\end{array}$ & $\begin{array}{r}-.91 \\
(-.2)\end{array}$ & $\begin{array}{l}1.16 \\
(.2)\end{array}$ & $\begin{array}{l}13.59 \\
(2.2)\end{array}$ & $\begin{array}{l}-10.8 \\
(-1.7)\end{array}$ & $\begin{array}{l}1.3 \\
(.3)\end{array}$ \\
\hline DNF QA & $\begin{array}{l}.10 \\
(.5)\end{array}$ & $\begin{array}{r}-.03 \\
(-1.5)\end{array}$ & $\begin{array}{r}.03 \\
(1.3)\end{array}$ & $\begin{array}{r}-.01 \\
(-.6)\end{array}$ & $\begin{array}{l}.06 \\
(.3)\end{array}$ & $\begin{array}{r}-.03 \\
(-1.5)\end{array}$ & $\begin{array}{r}.04 \\
(1.8)\end{array}$ & $\begin{array}{r}.03 \\
(1.5)\end{array}$ & $\begin{array}{r}1.80 \\
(17.1)\end{array}$ & $\begin{array}{l}-1.32 \\
(-6.1)\end{array}$ & $\begin{array}{r}.92 \\
(3.7)\end{array}$ & $\begin{array}{r}-.75 \\
(-3.0)\end{array}$ & $\begin{array}{r}.83 \\
(3.4)\end{array}$ & $\begin{array}{r}-.74 \\
(-3.0)\end{array}$ & $\begin{array}{l}.18 \\
(.9)\end{array}$ & $\begin{array}{r}.05 \\
(.7)\end{array}$ \\
\hline NGNP & $\begin{array}{r}1.00 \\
(8.8)\end{array}$ & $\begin{array}{r}-.15 \\
(-1.0)\end{array}$ & $\begin{array}{r}.03 \\
\cdot(.2)\end{array}$ & $\begin{array}{l}-.10 \\
(-.2)\end{array}$ & $\begin{array}{l}-.06 \\
(-.4)\end{array}$ & $\begin{array}{r}.16 \\
(1.0)\end{array}$ & $\begin{array}{c}.03 \\
(.2)\end{array}$ & $\begin{array}{l}.11 \\
(.8)\end{array}$ & $\begin{array}{l}-.17 \\
(-.2)\end{array}$ & $\begin{array}{l}1.27 \\
(.8)\end{array}$ & $\begin{array}{r}-2.29 \\
(-1.3)\end{array}$ & $\begin{array}{r}2.51 \\
(1.4)\end{array}$ & $\begin{array}{r}-2.99 \\
(-1.7)\end{array}$ & $\begin{array}{r}3.48 \\
(2.0)\end{array}$ & $\begin{array}{r}-2.89 \\
(-2.0)\end{array}$ & $\begin{array}{r}1.03 \\
(1.8)\end{array}$ \\
\hline RCP & $\begin{array}{r}5.29 \\
(4.0)\end{array}$ & $\begin{array}{l}-3.11 \\
(-1.8)\end{array}$ & $\begin{array}{l}-.78 \\
(-.4)\end{array}$ & $\begin{array}{l}-1.16 \\
(-.7)\end{array}$ & $\begin{array}{c}.41 \\
(.2)\end{array}$ & $\begin{array}{l}-1.30 \\
(-.7)\end{array}$ & $\begin{array}{r}.07 \\
(0.0)\end{array}$ & $\begin{array}{c}.25 \\
(.2)\end{array}$ & $\begin{array}{l}3.36 \\
(.4)\end{array}$ & $\begin{array}{r}-.83 \\
(-0.0)\end{array}$ & $\begin{array}{l}-7.68 \\
(-.4)\end{array}$ & $\begin{array}{l}-3.88 \\
(-.2)\end{array}$ & $\begin{array}{r}14.6 \\
(.7)\end{array}$ & $\begin{array}{l}2.65 \\
(.1)\end{array}$ & $\begin{array}{r}-11.8 \\
(-.7)\end{array}$ & $\begin{array}{l}4.07 \\
(.6)\end{array}$ \\
\hline
\end{tabular}

Impulse responses, shown in the upper left panels of Charts 3 and 4 for the bivariate systems provide the first important result regarding the effects of minor changes in the specification. The ordering of variables follows Friedman's work with NGNP preceding the financial aggregate in constructing the

aggregates, the implications of economic theory are not readily apparent. This question deserves further detailed attention. For monetary aggregates, the relevant theory exists and the impulse responses can be assessed on the basis of their correspondence with this theory. Since Friedman did not use this criterion and, in the interest of brevity, this issue is not pursued here. It is worth noting, however, that this issue has been examined in the context of St. Louis reduced form equations by Charles Freedman of the Bank of Canada and Tom Gittings of the Federal Reserve Bank of Chicago.

Tabie III

\begin{tabular}{|c|c|c|c|c|c|c|c|c|}
\hline \multirow[b]{3}{*}{ Quartiter } & \multicolumn{4}{|c|}{ Domestic Nortinancial Debr (DNF) } & \multicolumn{2}{|c|}{$M 1$} & \multirow{2}{*}{\multicolumn{2}{|c|}{$\frac{M 2}{\text { Quarierly Average }}$}} \\
\hline & Quolter & Average & & varter & Ouarter & verage & & \\
\hline & (NGWP. F) & $(F$, NGNP $)$ & $($ NGNP, F) & $(6$, NGNP) & $($ NGGN, F) & $(F, N G N P)$ & (NGMP, F) & (F, NGNP) \\
\hline 1 & 1 & -.95 & 1 & -.29 & 1 & .46 & 1 & .74 \\
\hline 2 & 1.5 & -.55 & .9 & -.42 & .63 & .05 & 1.35 & 1.06 \\
\hline 3 & .15 & -1.52 & .12 & -.94 & -.06 & -.58 & .92 & .65 \\
\hline 4 & -.004 & -1.37 & .003 & -.9 & -.04 & -.56 & .84 & .61 \\
\hline 5 & -.73 & -1.61 & -.38 & -.99 & -.27 & -.71 & .85 & 71 \\
\hline 0 & -.3 & -.76 & -.11 & -.5 & -.07 & -.36 & .89 & .83 \\
\hline 7 & -.49 & -.89 & -.6 & -.44 & .31 & -.06 & .89 & .85 \\
\hline 8 & -.88 & -1.35 & -.29 & -.87 & -.03 & -.28 & .45 & .46 \\
\hline 9 & -.15 & -.77 & -.25 & -.65 & -.12 & -.28 & -.01 & .04 \\
\hline 10 & .25 & $-4^{2}$ & -.23 & -.68 & .11 & -.12 & -.28 & -.24 \\
\hline 11 & .59 & -.17 & -.11 & -.58 & .02 & -.13 & -.49 & -.46 \\
\hline 12 & 1.02 & .28 & .19 & -.44 & .17 & .01 & -.67 & -.64 \\
\hline 13 & .88 & .18 & -.02 & -.44 & .15 & -.02 & -.8 & -.77 \\
\hline 14 & .85 & .17 & .02 & -.36 & -.11 & -.18 & -.86 & -.82 \\
\hline 15 & 1.08 & .35 & .08 & -.27 & -.03 & -.04 & -.79 & \\
\hline 16 & 1.12 & .34 & .17 & -.19 & .11 & .03 & -.63 & -.59 \\
\hline 17 & 1.16 & .36 & .27 & -.12 & .06 & .03 & -.49 & -.46 \\
\hline 18 & 1.1 & .31 & .29 & -.11 & .14 & .1 & -.39 & -.38 \\
\hline 19 & .91 & .18 & .31 & -.09 & .05 & .02 & -3 & $\begin{array}{l}.00 \\
-.3\end{array}$ \\
\hline 20 & .88 & .21 & .34 & -.06 & $\begin{array}{r}.03 \\
-.01\end{array}$ & $\begin{array}{r}.02 \\
-.04\end{array}$ & -.22 & -.23 \\
\hline 21 & .85 & .24 & .36 & -.03 & .12 & .1 & -.14 & -.16 \\
\hline 22 & .78 & .23 & .39 & .01 & .1 & .08 & $\begin{array}{l}-14 \\
-.09\end{array}$ & -.12 \\
\hline 23 & .76 & .25 & .39 & .04 & .07 & .07 & -.07 & \\
\hline 24 & .73 & .25 & .39 & .05 & 1 & .08 & .07 & -.09 \\
\hline
\end{tabular}

impulse response function. That is; the innovation in GNP is assumed to be independent of all the other innovations. The responses to M1 shocks (upper left panel of Chart 3) appear fairly stable by Friedman's criteria; although the response function oscillates with a short period, it damps out rather quickly. We examine the debt series, DNF, as end-of-quarter series (as in Friedman's work) and as a "quarterly average" series to maintain comparability with the way the monetary aggregates are targeted. ${ }^{15}$ The responses reported in the upper left-hand panel of Chart 3 for DNF using both measurement schemes seem considerably less stable than the M1 responses. The picture of DNF's impulse response function that emerges is somewhat different from that obtained by Friedman partly because he displayed the response function for only 20 quarters; the difference between ${ }^{15}$ The not seasonally adjusted series on an end-of-quarter
basis were taken from the Federal Reserve Board's flow-
of-funds databank in February 1983 . They were season-
ally adjusted using Statistics Canada's multiplicative,
quarterly version of X-11 ARIMA. At the time this
work was completed there was a discontinuity in the data
when the International Banking Act facility was phased
in at the end of 1981. To limit the effect of this "outlier"
on the estimates of the seasonal factors, the seasonal
adjustment estimation period stopped in $1981: Q 4$. The
forecasted adjustments for 1982 were then used to adjust
the 1982 data. The quarterly average debt series were
constructed as the average of the adjacent end-of-quarter
figures. The revised series for M1 and M2 do not cover
the period before $1959: Q 1$. To construct data for this
period we took the unrevised growth rates of the aggre-
gates and extrapolated backwards from the revised 1959 :
Q1 levels. Since no end-of-quarter series exists for the
monetary aggregates, we could not examine M1 and M2
on this basis. 


\begin{tabular}{|c|c|c|c|c|c|c|c|}
\hline \multicolumn{8}{|c|}{ Coefficients on Lagged RCP } \\
\hline 1 & 2 & 3 & 4 & 5 & 6 & 7 & 8 \\
\hline $\begin{array}{c}-.019 \\
(-3.5)\end{array}$ & $\begin{array}{l}.009 \\
(1.0)\end{array}$ & $\begin{array}{c}.014 \\
(1.4)\end{array}$ & $\begin{array}{c}-.022 \\
(-2.0)\end{array}$ & $\begin{array}{c}.017 \\
(1.5)\end{array}$ & $\begin{array}{c}-.011 \\
(-1.0)\end{array}$ & $\begin{array}{l}-.002 \\
(-.3)\end{array}$ & $\begin{array}{l}.001 \\
(.3)\end{array}$ \\
\hline $\begin{array}{l}.000 \\
(0.0)\end{array}$ & $\begin{array}{l}-.025 \\
(-1.5)\end{array}$ & $\begin{array}{l}.036 \\
(2.0)\end{array}$ & $\begin{array}{l}-.044 \\
(-2.1)\end{array}$ & $\begin{array}{l}.034 \\
(1.7)\end{array}$ & $\begin{array}{c}-.018 \\
(-1.0)\end{array}$ & $\begin{array}{l}-.008 \\
(-.5)\end{array}$ & $\begin{array}{l}-.002 \\
(-.2)\end{array}$ \\
\hline $\begin{array}{r}1.25 \\
(11.1)\end{array}$ & $\begin{array}{r}-.87 \\
(-4.8)\end{array}$ & $\begin{array}{r}.88 \\
(4.4)\end{array}$ & $\begin{array}{r}-.39 \\
(-1.7)\end{array}$ & $\begin{array}{l}.15 \\
(.6)\end{array}$ & $\begin{array}{r}-.24 \\
(-1.2)\end{array}$ & $\begin{array}{r}.19 \\
(1.0)\end{array}$ & $\begin{array}{r}-.11 \\
(-1.0)\end{array}$ \\
\hline $\begin{array}{l}.004 \\
(1.5)\end{array}$ & $\begin{array}{l}-.013 \\
(-3.1)\end{array}$ & $\begin{array}{l}.004 \\
(.9)\end{array}$ & $\begin{array}{l}-.009 \\
(-1.9)\end{array}$ & $\begin{array}{c}.009 \\
(1.7)\end{array}$ & $\begin{array}{l}-.007 \\
(-1.4)\end{array}$ & $\begin{array}{c}.006 \\
(1.3)\end{array}$ & $\begin{array}{l}-.006 \\
(-2.1)\end{array}$ \\
\hline $\begin{array}{l}.002 \\
(.2)\end{array}$ & $\begin{array}{r}-.03 \\
(-1.8)\end{array}$ & $\begin{array}{l}.020 \\
(1.2)\end{array}$ & $\begin{array}{l}-.015 \\
(-.8)\end{array}$ & $\begin{array}{l}.009 \\
(.5)\end{array}$ & $\begin{array}{l}-.002 \\
(-.1)\end{array}$ & $\begin{array}{l}-.014 \\
(-.9)\end{array}$ & $\begin{array}{l}-.001 \\
(-0.0)\end{array}$ \\
\hline $\begin{array}{r}1.20 \\
(10.6)\end{array}$ & $\begin{array}{r}-.79 \\
(-4.5)\end{array}$ & $\begin{array}{r}.83 \\
(4.4)\end{array}$ & $\begin{array}{r}-.42 \\
(-2.0)\end{array}$ & $\begin{array}{l}.36 \\
(1.6)\end{array}$ & $\begin{array}{r}-.44 \\
(-2.1)\end{array}$ & $\begin{array}{l}.12 \\
(.6)\end{array}$ & $\begin{array}{l}0.0 \\
(0.0)\end{array}$ \\
\hline $\begin{array}{l}.002 \\
(1.7)\end{array}$ & $\begin{array}{c}-.006 \\
(-2.8)\end{array}$ & $\begin{array}{l}.001 \\
(.5)\end{array}$ & $\begin{array}{c}-.004 \\
(-1.6)\end{array}$ & $\stackrel{.004}{(1.3)}$ & $\begin{array}{l}-.003 \\
(-1.0)\end{array}$ & $\begin{array}{l}.002 \\
(.9)\end{array}$ & $\begin{array}{l}-.003 \\
(-1.9)\end{array}$ \\
\hline $\begin{array}{c}.001 \\
(0.0)\end{array}$ & $\begin{array}{l}-.023 \\
(-1.5)\end{array}$ & $\begin{array}{l}.016 \\
(.9)\end{array}$ & $\begin{array}{l}-.013 \\
(-.7)\end{array}$ & $\begin{array}{l}.009 \\
(.4)\end{array}$ & $\begin{array}{l}-.002 \\
(-0.0)\end{array}$ & $\begin{array}{l}-.012 \\
(-.9)\end{array}$ & $\begin{array}{l}-.002 \\
(-.2)\end{array}$ \\
\hline $\begin{array}{r}1.19 \\
(10.4)\end{array}$ & $\begin{array}{r}-.77 \\
(-4.3)\end{array}$ & $\begin{array}{r}.83 \\
(4.2)\end{array}$ & $\begin{array}{r}-.42 \\
(-1.9)\end{array}$ & $\begin{array}{r}.38 \\
(1.6)\end{array}$ & $\begin{array}{c}-.46 \\
(-2.10)\end{array}$ & $\begin{array}{l}.14 \\
(.7)\end{array}$ & $\begin{array}{l}-.009 \\
(-0.0)\end{array}$ \\
\hline
\end{tabular}

\begin{tabular}{|c|c|c|c|c|c|c|c|}
\hline Constant & Trend & $F_{\text {financial }}$ & ${ }^{F_{\text {GNP }}}$ & $F_{\text {RCP }}$ & $\bar{R}^{2}$ & $Q(30)$ & $\begin{array}{l}\text { Residual } \\
\text { Standard } \\
\text { Doviation }\end{array}$ \\
\hline $\begin{array}{l}.019 \\
(.4)\end{array}$ & $\begin{array}{l}.00013 \\
(.4)\end{array}$ & 193.2 & 5.00 & 5.30 & .9998 & 11.17 & .0043 \\
\hline $\begin{array}{r}.19 \\
(2.2)\end{array}$ & $\begin{array}{l}.0013 \\
(2.4)\end{array}$ & 1.97 & 35.0 & 2.74 & .9998 & 18.41 & .0078 \\
\hline $\begin{array}{l}-1.22 \\
(-1.2)\end{array}$ & $\begin{array}{l}-.0076 \\
(-1.2)\end{array}$ & 2.95 & 1.42 & 52.8 & .9667 & 12.65 & .0873 \\
\hline $\begin{array}{c}.081 \\
(3.2)\end{array}$ & $\begin{array}{c}.0050 \\
(4.4)\end{array}$ & 307.8 & 2.30 & 6.0 & .9999 & 27.15 & .0022 \\
\hline $\begin{array}{r}.220 \\
(2.30)\end{array}$ & $\begin{array}{c}.0012 \\
(2.8)\end{array}$ & .65 & 42.0 & 2.33 & .9998 & 16.60 & .0083 \\
\hline $\begin{array}{l}-.629 \\
(-.6)\end{array}$ & $\begin{array}{l}-.0015 \\
(-.3)\end{array}$ & 1.23 & 2.83 & 40.5 & .9821 & 12.66 & .0931 \\
\hline $\begin{array}{c}.04 \\
(3.2)\end{array}$ & $\begin{array}{l}.0003 \\
(4.4)\end{array}$ & 1133.9 & 2.95 & 5.61 & .9999 & 25.87 & .0012 \\
\hline $\begin{array}{l}.209 \\
(2.2)\end{array}$ & $\begin{array}{l}.0012 \\
(2.8)\end{array}$ & .88 & 43.0 & 2.06 & .8998 & 13.93 & .0082 \\
\hline $\begin{array}{l}-.73 \\
(-.7)\end{array}$ & $\begin{array}{l}-.0019 \\
(-.4)\end{array}$ & .91 & 2.54 & 39.4 & .9611 & 10.95 & .09439 \\
\hline
\end{tabular}

Chart 3

\section{IMPULSE RESPONSE FUNCTIONS FOR M1 AND DNF} RESPONSE OF F/NGNP TO A $1 \%$ SHOCK IN F

2 Variable System Ordered (NGNP, F)

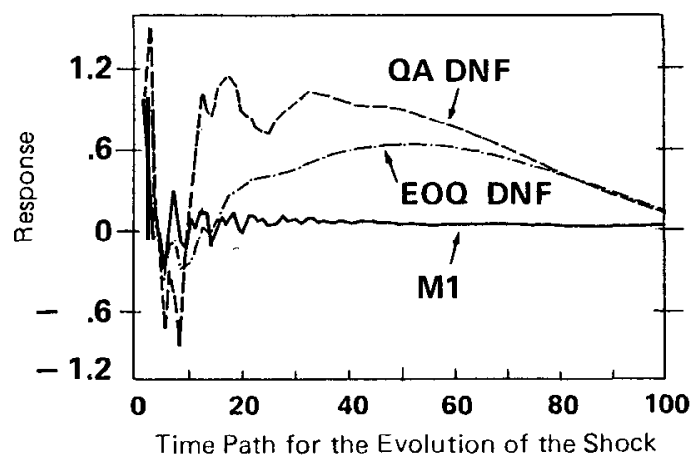

3 Variable System Ordered (RCP, NGNP, F)

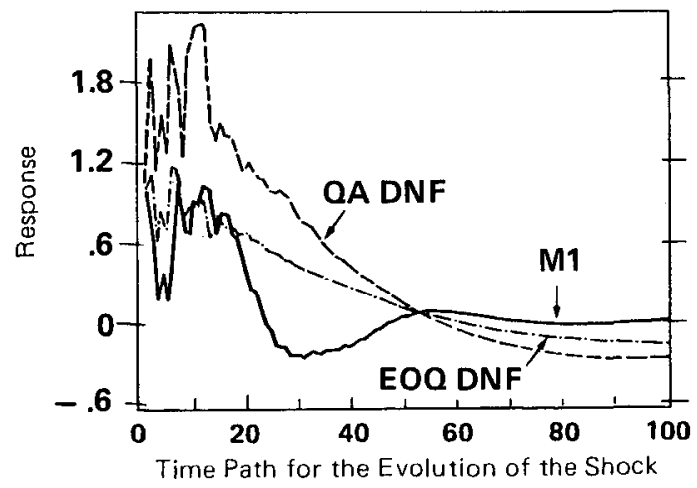

3 Variable System Ordered (XGNP, PGNP, F)

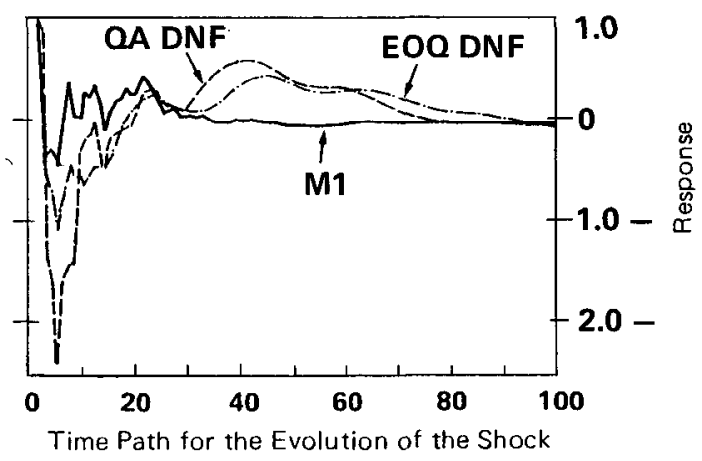

4 Variable System Ordered (RCP, XGNP, PGNP, F)

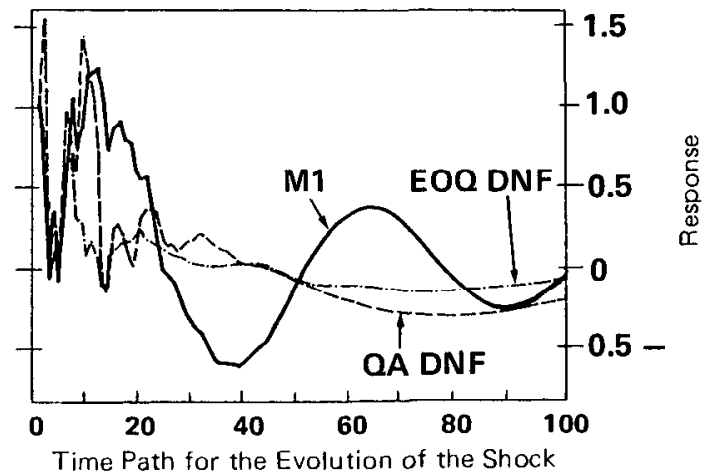




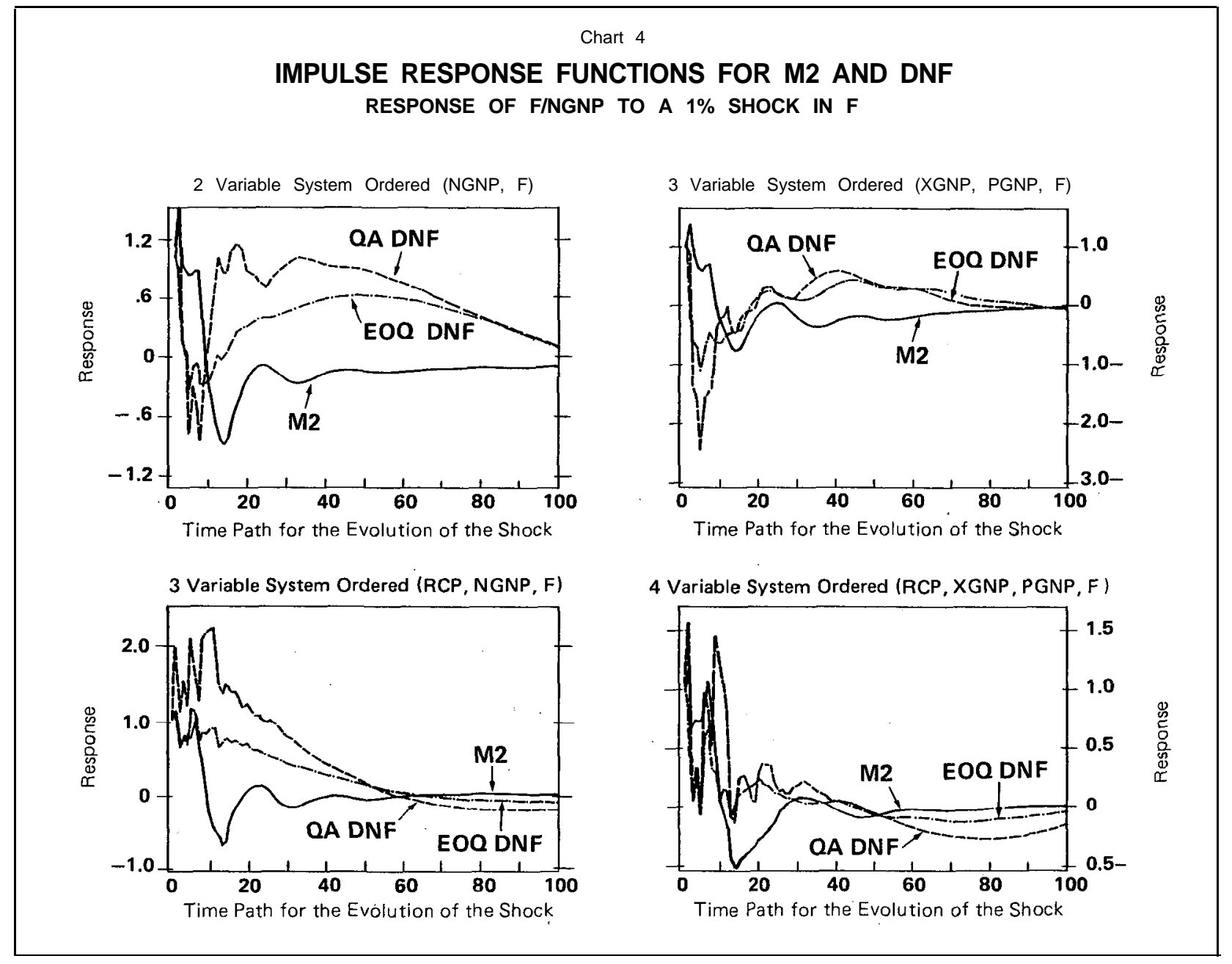

M1 and end-of-quarter DNF is more evident beyond the 20th lag. The impulse response for M2 in the bivariate model (upper left panel of Chart 4) also seems fairly stable. The responses of quarterly average data are considerably less stable than those of the end-of-quarter data. These results do not support the notion that the credit aggregate is as stable as the monetary aggregates in impulse response functions derived from the bivariate system.

Table III displays the impulse response function from period 1 to 24 for $\mathrm{DNF}$ and the two monetary aggregates using both orderings-( F, NGNP) and (NGNP, F)-and both measures of DNF. (Recall that Charts 3 and 4 used the (NGNP, F) ordering.) As noted above, one of the drawbacks of the impulse response functions is their sensitivity to the ordering of variables when the innovations are correlated. The correlation of the innovations is .31 in the system with quarterly average DNF, .38 in the system with end-of-quarter DNF, .32 in the system with M1, and only .16 with M2. Though the M1 and DNF correlations are similar, the DNF impulse response functions differ much more on average in the alternative orderings than the M1 response (lower panel of Table IV). With the smallest correlation in the innovations, M2 exhibits the smallest difference in the impulse response function in the alternative orderings.

Trivariate systems with a financial aggregate, real GNP (XGNP) and the implicit GNP deflator (PGNP) (upper right-hand panels of Charts 3 and 4 or with nominal GNP, the commercial paper rate and a financial aggregate (lower left-hand panels) also favor the monetary aggregates over the credit aggregates. In the systems with XGNP, PGNP and $\mathrm{F}$, the M1 impulse responses are noticeably smoother than the DNF responses (quarterly average and endof-quarter). Impulse responses for end-of-quarter DNF are once again also smoother than for their quarterly average counterparts. Furthermore, while 
the M1 responses in the bivariate system are similar to the M1 responses in the trivariate XGNP, PGNP, F system, DNF's velocity responses in the analogous trivariate system have greater amplitude than in the bivariate system with DNF. Fairly similar results are also obtained for the M2-DNF comparison in this system.

Three variable systems (NGNP, $F$ and the commercial paper rate (RCP)) provide the most striking example of the difference between quarterly average and end-of-quarter data construction (lower left panels). For the M1-DNF comparison, the end-ofquarter DNF responses are considerably smooth\& than M1 responses and are somewhat more damped. On the other hand, the quarterly average DNF impulse responses are much more variable than their M1 counterparts. In addition, the estimated lag coefficients on credit in the VAR NGNP equation that lies behind this impulse response function are not significant at the 50 percent significance level while corresponding M1 parameters are significant just above the five percent significance level. ${ }^{16}$ Similar results also hold for a comparison of M2 and DNF.

Four-variable systems (real GNP, the price deflator, the commercial paper rate and a financial aggregate) lend some support to Friedman's notions that DNF has about as stable relationship to GNP

\footnotetext{
${ }^{16}$ The joint significance of the F-test for DNF and M1 have significance levels of .539 and .059 , respectively ( Table II)
}

Tablo iv

SUMMARY STATISTICS FOR IMPULSE RESPONSE FUNCTIONS

\begin{tabular}{ccccc} 
Aggregate & $\begin{array}{c}\text { Method of } \\
\text { Meosurement }\end{array}$ & Ordering & Averag*2 & $\begin{array}{c}\text { Average Sum } \\
\text { of Squares }^{3}\end{array}$ \\
\hline DNF & QA & (NGNP, F) & .54 & .70 \\
& EOQ & (NGNP, F) & .13 & .15 \\
DNF & QA & (F, NGNP) & -.29 & .54 \\
& EOQ & (F, NGNP) & -.38 & .24 \\
M1 & QA & (NGNP, F) & .10 & .07 \\
& QA & (F, NGNP) & -.10 & .07 \\
M2 & QA & (NGNP, F) & .04 & .44 \\
& QA & (F, NGNP) & -.01 & .33
\end{tabular}

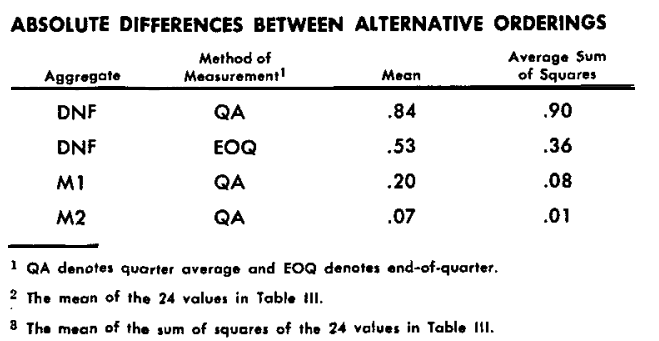

as the monetary aggregates. In these systems M1 and M2 variability is greater over some range (from 20 to 80 quarters) than is the associated variability of DNF. However, the credit aggregates damp more slowly than M1 or M2 and, as with the three variable systems containing interest rates, the influence of credit on GNP is much weaker than the influence of M1 (or M2) on GNP. ${ }^{17}$

\section{Variance Decompositions}

As noted in Section II, the variance decomposition (VARD) results may be useful in judging whether the direction of influence in the relationship between a given financial aggregate and a policy objective (such as nominal GNP) runs from the aggregate to the objective or vice-versa. Entries in Charts 5-8 report the share of the total forecast error variance of a given variable that can be attributed to independent movements in the innovations of the same or another variable. For example, the left panel of Chart 5 displays the variance decomposition of NGNP in a bivariate model containing NGNP and M1 with M1 taken first in the ordering and NGNP second, (M1, NGNP). This chart shows that, at a lag of 10 quarters, about one-third of the variance of NGNP can be attributed to current and lagged shocks in NGNP with the remainder attributable to current and lagged shocks in M1.

Charts 5-7 display the VARDs of NGNP and F for bivariate models. For M1 and M2 in both orderings the contribution of the monetary aggregate in explaining NGNP tends to increase or stay the same over the entire range of lags shown. The credit aggregate DNF, on the other hand, explains an increasing share of NGNP until a lag of about 10

\footnotetext{
${ }^{17}$ The discussion in the text refers only to systems estimated with eight lags on all the variables. This lag length was chosen for comparability with Friedman's work but various F-tests for the significance of coefficients on lags 5-8 suggest that only the first four lags are significant. For all the nominal GNP equations in systems mentioned above we tested whether the coefficients of variables lagged 5 to 8 periods were significantly different from zero. For systems involving DNF and M1 we were never able to reject this hypothesis at the 5 percent level of significance. In the systems with real GNP and prices we tested the significance of the lag 5 to lag 8 coefficients in both the real GNP equations and the price equations. Again for the equations we checked we could not reject the hypothesis that these coefficients were zero at the 5 percent level of significance for systems with M1 and DNF. In general, the overall patterns of responses for four-lag systems, Offenbacher and Porter [1983, Charts 8 and 9], confirm the comparisons made above between money and credit aggregates. The main difference between the four- and eight-lag systems is that the latter have more cyclical impulse response patterns-a result that is not surprising.
} 


\section{VARIANCE DECOMPOSITIONS OF NGNP FOR BOTH ORDERINGS OF A BIVARIATE SYSTEM WITH NGNP AND M1}
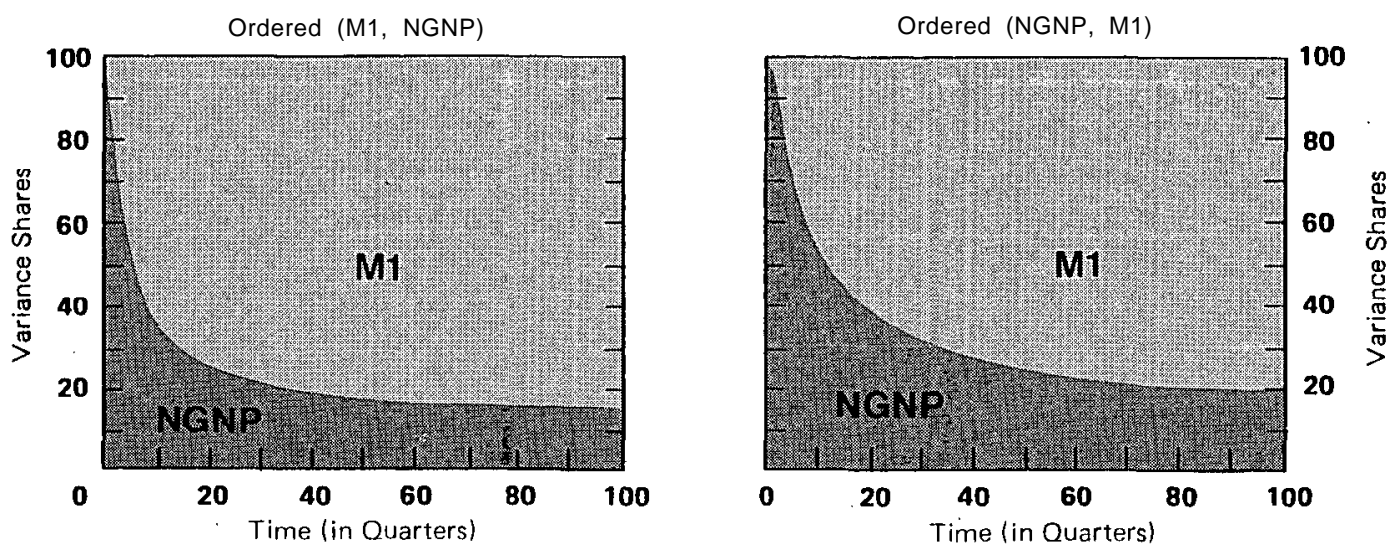

quarters, and thereafter its contribution decreases in both orderings. In the VARDs for financial aggregates, M1 and M2 explain a greater proportion of their own variance when they are ordered second in the system, while the reverse is true for DNF. On balance, the monetary aggregates in these bivariate specifications respond much less to movements in NGNP over time than does the credit aggregate. ${ }^{18}$

The most interesting results are those associated with the inclusion of interest rates (Chart 8). The contrast between the results for the two-variable and three-variable systems containing NGNP, RCP, and $F$ is most striking for DNF. In the three-variable system DNF's role shrinks drastically. This debt measure explains a very small percentage of NGNP in both orderings examined, (DNF, RCP, NGNP) and (RCP, NGNP, DNF)-under 8 percent at all lags-whereas in the two-variable system it accounted for about 40 to 70 percent of the variance of NGNP after 10 quarters, depending on the ordering. ${ }^{19} \mathrm{O} \mathrm{n}$ the other hand, the M1 contribution levels off to

\footnotetext{
${ }^{18}$ In the trivariate system (XGNP, PGNP and F) the monetary aggregate M2 appears to do the best job of explaining movements "in each component of "the threevariable system at least after 10 quarters or so. For example, in the VARDs for the deflator, M2 eventually explains between 70 and 85 percent of the variance of the price deflator, depending on the ordering; M1 and DNF, on the other hand, each explain considerably less of the variation, in prices. See Offenbacher and Porter [1983, Charts 14 to 17 ).

${ }^{19}$ See Offenbacher and Porter [1983] for a more complete description of the results including those for the ordering (RCP, NGNP, F).
}

around.20 percent. Thus, while none of the financial aggregates' innovations has a large role in explaining NGNP, the two monetary aggregates have a stronger influence than the credit aggregate. ${ }^{20}$

Another interesting feature of the trivariate systems with interest rates is the reciprocal influence of RCP and the financial aggregates, i.e., the influence of innovations in each of these variables on movement in the other. On the basis of this comparison, DNF clearly appears as an endogenous variable since its innovations account for at most two percent of RCP's forecast error variance while RCP's innovations account for over 80 percent of DNF's forecast error

\footnotetext{
${ }^{20}$ The effects of including an interest rate that are reported here are qualitatively similar to the effects of including an interest rate in another vector autoregression that started out with $\mathrm{M} 1$, industrial production and the CPI. Those results were reported by Sims [1980A]. Friedman also did some work with interest rates but the results he reports are not as extensive as the ones reported here. Friedman reports a strong influence of interest rates. He interprets this result as being consistent with his policy proposal to add a credit aggregate target on the grounds that both interest rates and the volume of credit convey similar information since they are determined in the same market, the credit market. There are at least two important difficulties with this conclusion. First, Friedman's interpretation of the role of interest rates is only one of a number of plausible explanations; some of the others would not support Friedman's policy proposal. Second, and more importantly, the magnitude of the interest rate's influence in the two systems is so much greater than the influence of the volume of credit that it seems hard to justify-a volume of credit target rather than an interest rate target. Of course, interest rate targeting has its own problems that need not be discussed here. The upshot is that a credit target does not seem justified on the grounds that Friedman proposes.
} 


\section{VARIANCE DECOMPOSITIONS OF NGNP FOR BOTH ORDERINGS OF A BIVARIATE SYSTEM WITH NGNP AND DNF}
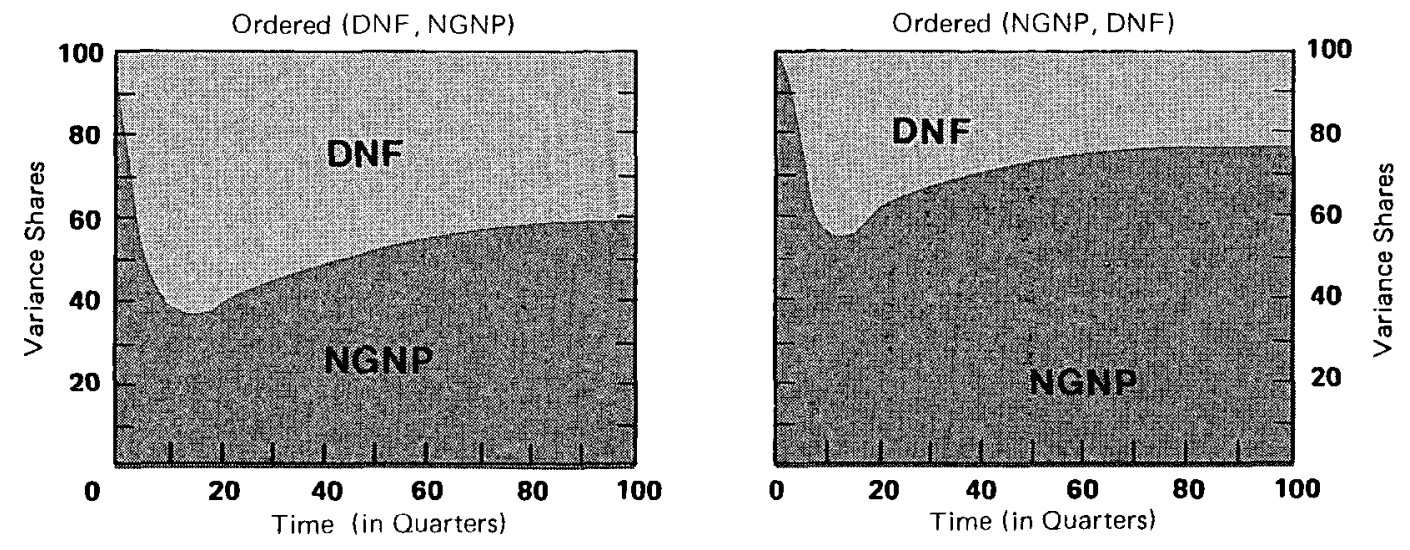

variance after 12 quarters. A similar comparison for M1 shows that RCP is about twice as important in explaining M1 than is M1 in explaining RCP regardless of the ordering. Furthermore, DNF innovations explain a considerably smaller share of both NGNP movements and movements in DNF itself as compared with the share of M1 innovations in explaining NGNP and M1 itself. ${ }^{21}$

${ }^{21}$ See Offenbacher and Porter [1983] for the detailed charts describing these results.

\section{CONCLUSIONS}

Though the monetary aggregates seem to fare somewhat better than the credit aggregate in the VAR exercises, on balance the results seem to be very sensitive to the methods of measuring the data, the ordering of the variables in the impulse response functions, or variance decompositions, and the inclusion of variables in the model. Thus, no reliable inferences may be drawn. When our results are considered along with Friedman's, it seems the most that

\section{VARIANCE DECOMPOSITIONS OF NGNP FOR BOTH ORDERINGS OF A BIVARIATE SYSTEM WITH NGNP AND M2}
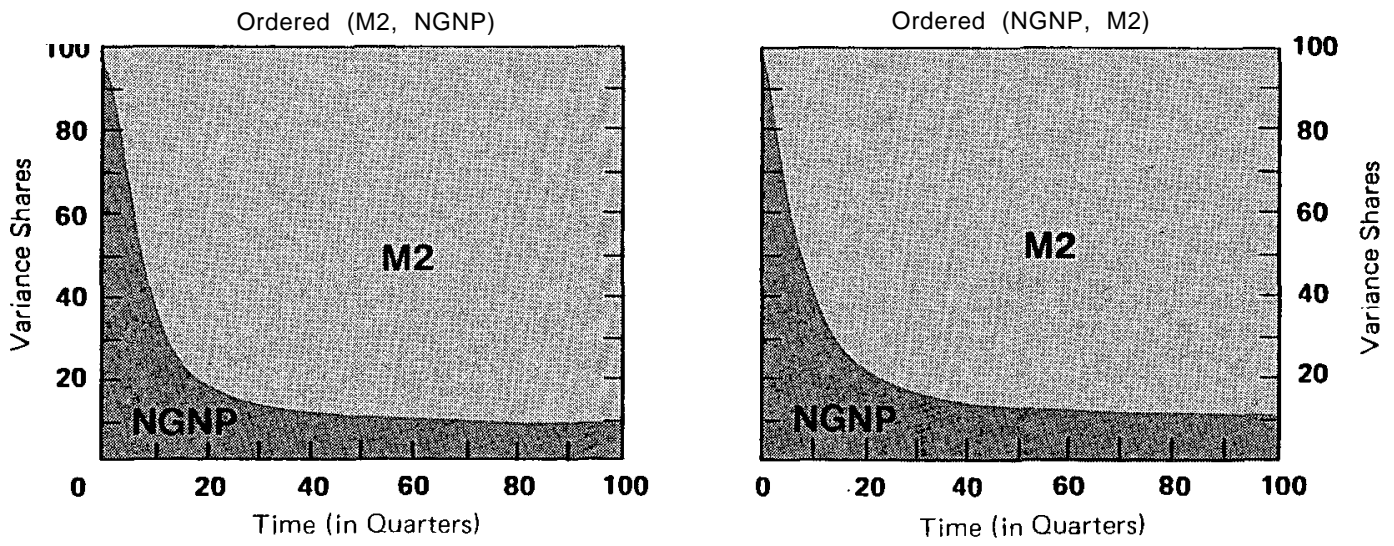


\section{VARIANCE DECOMPOSITIONS OF NGNP FOR TWO ORDERINGS OF TRIVARIATE SYSTEMS}
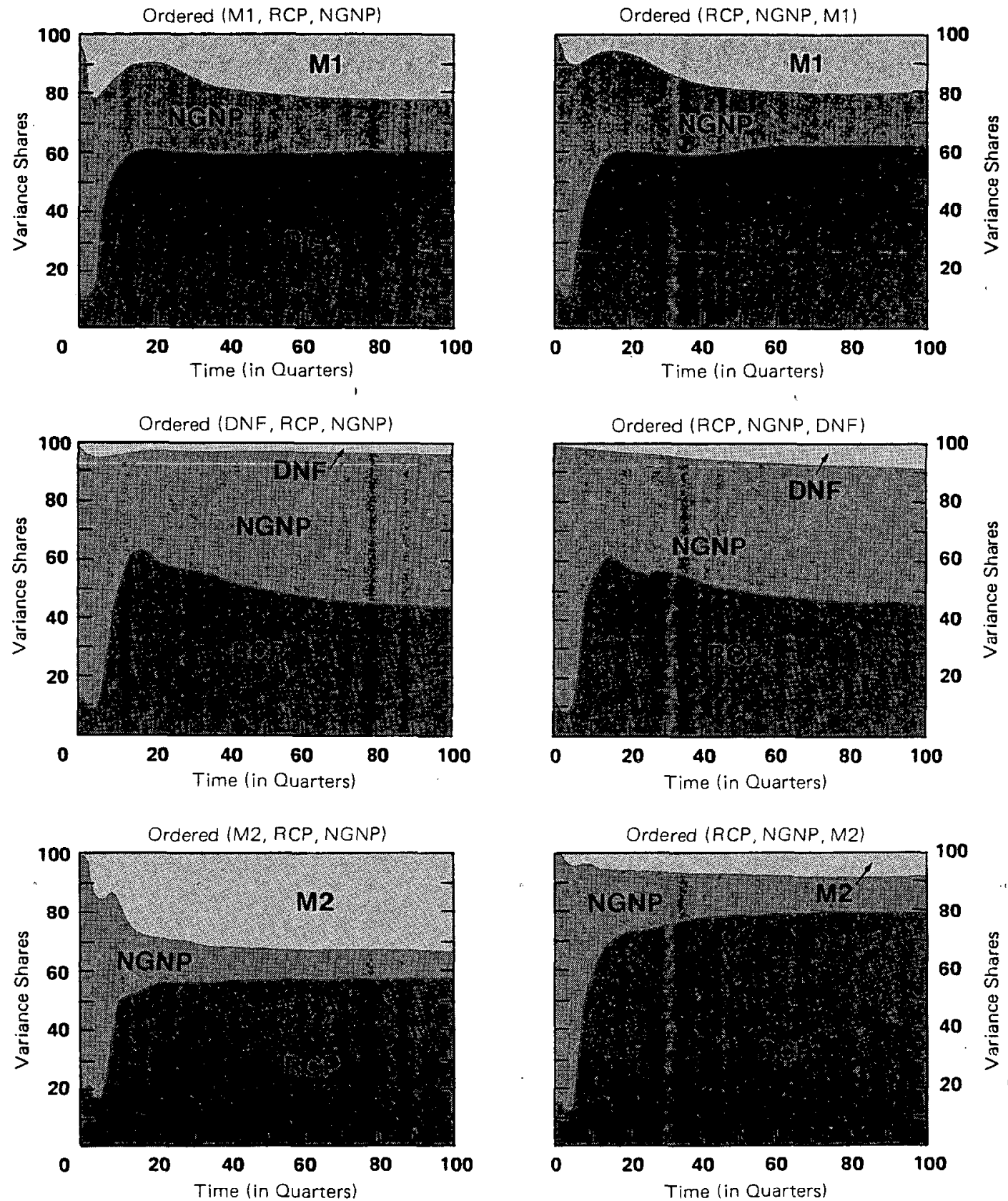

can be said in Friedman's favor is that VAR methods are not capable of distinguishing the proper monetary policy target.

Finally, a more fundamental characteristic of the VAR methodology must be recognized. Suppose, for the sake of argument, that the empirical analysis were to indicate that DNF had more desirable properties than the monetary aggregates in the impulse response functions and variance decompositions. Would this justify targeting DNF (or M1 in the opposite case)? 
Since the VAR model is not a structural model, it cannot predict the effects on the economy of a structural change such as the adoption of a specific monetary policy for debt expansion. Because the VAR model is a reduced-form model, changes in the structure, including policy regime changes, will tend to alter the VAR coefficients. Rather, the VAR model functions as a data reduction device. Because structural economic theories of debt have not reached the empirical stage, such "black box" devices may be helpful only in pinpointing empirical regularities, in forecasting (without policy implications), and in providing theorists with useful insights in the sense that empirically valid structural models can be expected to generate reduced forms with properties similar to the properties of the black box reduced forms. However, VAR models should not be used to make structural policy inferences. ${ }^{22}$

${ }^{22}$ See Cooley and LeRoy [1982] for a forceful discussion of the issues raised in this paragraph.

\section{References}

Cooley, Thomas F. and Stephen F. LeRoy, "Atheoretical Macroeconomics : A Critique," reproduced, University of California, Santa Barbara, (December 1982).

Doan, Thomas, Robert Litterman, and Christopher Sims. "Forecasting and Conditional Projections with Realistic Prior Distributions," NBER Working Paper no. 1202, (1983), forthcoming in Communications in Statistics: Econometric Reviews.

Friedman, Benjamin M., "The Relative Stability of Money and Credit 'Velocities' in the United States: Evidence and Some. Speculations," Cambridge, Mass.,., NBER Working Paper no. 645, (March 1981).

"Debt and Economic Activity in the United States." in Benjamin M. Friedman (ed.), The Changing Roles of Debt and Equity in Financing U.S. Capital Formation, Chicago: University of Chicago Press, 1982.

"The Roles of Money and Credit in Macroeconomic Analysis," in James Tobin (ed.), Macroeconomics, Prices and Quantities: Essays in Memory of Arthur M. Okun. Washington: The Brookings Institution, 1983A.

"Monetary Policy With a Credit Aggregate Target," in Karl Brunner and Allan H. Meltzer (eds.), Money, Monetary Policy, and Financial Institutions (Supplement no. 18 to Journal of Monetary Economics), Amsterdam: North-Holland Publishing Co., 1983B.

Gordon, Robert J. and Stephen R. King, "The Output Cost of Disinflation in Traditional and Vector Autoregressive Models," Brookings Papers on EConomic Activity, 1982:1, pp. 205-244.

Gordon, Roger H., "Interest Rates, Inflation, and Corporate Financial Policy," Brookings Papers on Economic Activity, 1982:2, pp. 461-488.

Holbrook, Robert S., "Optimal Economic Policy and the Problem of Instrument Instability," American Economic Review, vol. 36, (March 1972), pp. 57-65.
Litterman, Robert, "Specifying Vector Autoregressions for Macroeconomic Forecasting," (1982) Research Department Working Paper no. 208, Federal Reserve Bank of Minnesota.

Offenbacher, Edward K., Richard D. Porter and Edward F. McKelvey, "Empirical Comparisons of Credit and Monetary Aggregates Using Vector Autoregression Methods," reproduced, Federal Reserve Board, (July 1982).

Offenbacher, Edward K. and Richard D. Porter, "Empirical Comparisons of Credit and Monetary Aggregates Using Vector Autoregression Methods," Special Studies Paper 181, Federal Reserve Board, (August 1983).

Papademos, Lucas and Franco Modigliani, "Inflation, Financial and Fiscal Structure, and the Monetary Mechanism," European Economic Review, (1983) vol. 21, pp. 203-250.

Sargent, Thomas J., "Estimation of Dynamic Labor Demand Schedules Under Rational Expectations," Journal of Political Economy, vol. 86, (December 1978), pp. 1009-1044.

Sims, Christopher, "A Comparison of Interwar and Postwar Business Cycles : Monetarism Reconsidered," American Economic Review, Papers and Proceedings, vol. 70, no. 2, (May 1980A), pp. 25057 .

rica, (1980B) vol. 48, no. 1, pp. 1-47.

"Policy Analysis With Econometric Models," Brookings Papers on Economic Activity, 1982:1, pp. 107-164.

Zellner, Arnold, "Causality and Econometrics," in Karl Brunner and Allan H. Meltzer (eds.), Three Aspects of Policy and Policymaking: Knowledge, Data, and Institutions (Supplement no. 10 to Journal of Monetary Economics), Amsterdam: North-Holland Publishing Co., 1979.

\section{A P PEN DIX A}

\section{Abbreviations Used in Text}

DNF - total credit market debt owed by domestic nonfinancial sectors

DP - the so-called "debt proxy" consisting of currency, deposits and credit market instruments held by private domestic nonfinancial sectors

EOQ - indicates that series measured on an end-ofquarter basis

F - a financial aggregate

M1 - quarterly average money supply measure

M2 - quarterly average money supply measure

MAR - moving average representation

NGNP -nominal GNP

PGNP - implicit GNP deflator (1972=100)

QA - indicates that series measured on a quarterly average basis

RCP - commercial paper rate (4-6 month)

VAR - vector autoregression

VARD - variance decomposition

XGNP - real GNP (1972 dollars) 


\title{
MONEY, CREDIT, AND FEDERAL RESERVE POLICY: REPLY TO PORTER AND OFFENBACHER
}

\author{
Benjamin M. Friedman*
}

I am grateful for the careful and painstaking effort that Richard Porter and Edward Offenbacher have devoted to replicating and extending parts of my empirical work on the relationship between nonfinancial economic activity and the economy's total net credit outstanding, and I welcome the chance to respond to their paper as an opportunity to comment on several important questions about monetary policy in the context of that relationship. My views on these issues are in agreement with those expressed by Porter and Offenbacher, at least in most respects.

The research that I and others have done, highlighting the credit-income relationship in the United States, raises two separate questions for the conduct of monetary policy :

(1) Should the Federal Reserve System formulate and implement monetary policy in terms of prespecified targets for the growth of a small number of financial aggregates?

(2) If the Federal Reserve does make monetary policy in this way, which aggregates should it use ?

In addition, Porter and Offenbacher raise a methodological issue about the statistical techniques employed in some parts of my empirical work on this subject:

(3) What light can the results of vector autoregression analysis shed on either of these questionsor, for that matter, on any other policy questions?

I shall comment in turn on each of these issues.

\section{Aggregate Targets for Monetary Policy}

As I have argued in some detail elsewhere, 'on strictly economic grounds the use of financial aggregate growth targets as the central focus of monetary policy is clearly inferior to more flexible policy procedures. If a financial aggregate bears a close and

\footnotetext{
* Professor of Economics, Harvard University.

${ }^{1}$ See Friedman (1975, 1977).
}

reliable relationship both to the ultimate economic objectives that the Federal Reserve wants monetary policy to affect (for example, price inflation and real economic growth) and to instruments directly under the Federal Reserve's control (for example, nonborrowed reserves or the federal funds rate), then it is at least plausible to conduct monetary policy by first determining what target growth rate for that aggregate is most likely to be consistent with the specific desired pattern of economic objectives and then conducting open market operations so as to achieve that growth target as closely as possible. As is now widely understood, this familiar two-step procedure is equivalent to using the chosen financial aggregate to summarize, in a specific way, all developments that affect the impact of monetary policy actions on the ultimate economic policy objectives.

The most obvious shortcoming of this two-step procedure is that it fails to take advantage of relevant information about such developments contained in readily observable variables other than the chosen aggregate. Moreover, except in extreme circumstances this procedure does not even use efficiently the information that the chosen aggregate does contain. The argument against the two-step procedure is essentially unchanged if the Federal Reserve bases policy on growth targets for more than one aggregate, although then there is the additional complication of determining the relative importance to be attached to each one.

On strictly economic grounds, therefore, the Federa1 Reserve should not use financial aggregate targets at all, but should instead use the most efficient available way of incorporating into its policy actions all relevant and available information-in practice, a combination of econometric tools applied to some areas and judgment applied to others that are less conducive to explicit quantitative treatment. Nevertheless, since the early 1970s the Federal Reserve has, with varying dedication, made growth targets for the standard monetary aggregates the principal focus of U. S. monetary policy, and the central banks of other major industrialized economies have adopted similar approaches. The reason, of course, is that 
more than strictly economic criteria typically are (and should be) apposite to the structuring of economic policy procedures. In the United States, the Federal Reserve is responsible to the Congress for the conduct of monetary policy, and Congress accordingly bears responsibility for overseeing the Federal Reserve's actions. In the course of seeking a policy framework that will enable it to execute this oversight responsibility, Congress has legislated a role for money and credit aggregates in the monetary policy process.

One theme running throughout Porter and Offenbacher's paper is that, although in the work on which they focus I have advocated the use of a credit target for monetary policy, the empirical results I have reported there do not make the bottom-line case for the use of such a target. Porter and Offenbacher are entirely correct in this regard. They are correct because the goal of this work was not to address the primary issue of whether the Federal Reserve should focus monetary policy on a growth target for credit or any other financial aggregate, but instead, taking as given that the Federal Reserve does use such targets, to ask the more limited question-discussed immediately below-of what specific aggregates it should use. Moreover, at a more fundamental level Porter and Offenbacher would be correct in this regard in any case, regardless of the objectives I had intended. Whatever justification there is for the use of financial aggregate growth targets in the monetary policy process must ultimately rest on political or organizational (bureaucratic) considerations, not economic ones. No set of empirical economic findings can resolve these conflicts.

\section{Money and Credit Aggregates}

If the Federal Reserve is going to use financial aggregate growth targets to formulate and implement monetary policy, it must specify which aggregates to target. The prevailing legislation simply refers to money and credit, appropriately leaving to the Federal Reserve the actual selection. In recent years (until 1983), the Federal Reserve has reported to Congress its targets for the growth of three monetary aggregates (M1, M2 and M3) and one credit aggregate (commercial bank credit).* In practice,

\footnotetext{
${ }^{2}$ Most observers believe that the Federal Reserve in practice placed little if any emphasis on the stated bank credit target, and Porter and Offenbacher reinforce this impression by ignoring that it ever existed. For a brief period, the Federal Reserve reported separate targets for M1-A and M1-B.
}

most observers have concluded that the narrow" M1 aggregate has been the principal focus of policy.

I have argued for the use of total net credit as an additional target for monetary policy, if policy is to have such targets at all, for three reasons each closely related to the structure of the policy process based on aggregate targets: First, because of the potential dangers of placing exclusive reliance on a single aggregate, using two targets is better than using one -especially when there is reason to believe that the two draw on disparate sources of, information from within the economy's financial markets. A credit aggregate, by drawing on the liability side of the economy's balance sheet, supplements the information about the economy's asset holding contained in the monetary aggregates, and thereby usefully diversifies the information base underlying the signals that presumptively matter for monetary policy. Second, in the United States the total net credit aggregate bears as close a relationship to nonfinancial economic activity as does any of the standard monetary aggregates. This relationship is also not simply that of a mirror reflecting what has already happened; rather, credit contains useful information about future movements of income and prices. Third, with some lag the total credit aggregate bears a relationship to the Federal Reserve's direct operating instruments that is roughly comparable to that for the standard monetary aggregates. Hence over time the Federal Reserve plausibly could, if it chose, influence the growth of total net credit.

Porter and Offenbacher focus their substantial and impressive efforts on my empirical results documenting the relationship between total net credit and U. S. nonfinancial economic activity. In particular, they replicate and extend the work, that I did using vector autoregression methods to examine dynamic aspects of this relationship. Their individual findings are not without interest, although in the end it is difficult to know in what way (if any) they affect the overall conclusion to be drawn from the analysis. As did I, Porter and Offenbacher find that monetary aggregates appear more closely related to nonfinancial economic activity in some specific contexts, while the credit aggregate is apparently more closely related in others. They usefully reinforce this ambiguity by demonstrating that many of the individual results are "quite sensitive to slight changes in either arbitrary or seemingly innocuous assumptions." Not all. of 
their changes and extensions are of equal merit, ${ }^{3}$ but on the whole the set of exercises they report provides a useful addition to understanding of the relationships involved.

I disagree in an important way with only two aspects of Porter and Offenbacher's attempt to contrast our mostly similar findings. The first is their interpretation of the implications of the effect of adding interest rates to vector autoregression systems including income and financial aggregates. Mehra and Sims had earlier shown that the appearance of a major role for money in the determination of income typically disappears upon the introduction of interest rates." Porter and Offenbacher show a similar result for the total net credit aggregate. In addition, using comparisons among respective variance decomposition analyses, they argue that the effect of introducing interest rates is even stronger for systems including credit than for systems including money. In my similar work on this subject, I have found results leading to somewhat different conclusions than those reached by Porter and Offenbacher, but I surely agree that the relationships under study are not invariant to the inclusion or exclusion of interest rates.

Indeed, nor should they be. No familiar theory of macroeconomic interaction implies that quantities matter while relative prices do not. As I have argued elsewhere, ${ }^{6}$ it is helpful to think of the systems under study here as consisting of three markets: those for goods and services, for money, and for credit. In addition to its three quantity variables, such a system has two relative prices; as usually stated, they are the price of goods in terms of money, and the price of credit in terms of money-that is, the interest rate. The primary thrust of my work on this subject is to argue that what happens in both the money market and the credit market is relevant to the determination of income. It is possible, of course, to attempt to capture the relevant information from the credit market by using only that market's quan-

\footnotetext{
${ }^{3}$ For example, I question the relevance in this context of distinctions found by extending the simulations past twenty quarters.

${ }^{4}$ See Mehra (1978) and Sims (1980).

${ }^{5}$ For example, in recent work with a six-variable system including real income, prices, money (M1), total net credit, the high-employment federal deficit as a percentage of potential income, and a short-term interest rate, Richard Clarida and I have found that the distributed lags on credit and the interest rate are each significant at the .10 level in the real income equation. See Clarida and Friedman (1984).

${ }^{6}$ See especially Friedman (1983).
}

tity, but presumably the associated price (the interest rate) matters too. The information contained in the credit quantity when it is the only aspect of that market included will in general differ from the information contained in the quantity when used in conjunction with the interest rate.

What is the implication, for the choice of monetary policy targets, of finding that interest rates do matter in this context, perhaps even more than either money or credit? One possible implication would be to reject financial aggregate growth targets altogether in favor of gauging policy entirely by interest rates, although that idea lies outside the scope of the work under study here. In addition, the problems with basing monetary policy entirely on nominal interest rates are well known. Another possible implication would be to argue for some combined money-and-interest-rate system. A third would be to choose a money-and-credit-and-interest-rate system. Any of these is plausible. But there is no reason to reject entirely the relevant information from the credit market just because some of that information is contained in the price (interest rate) rather than the quantity variable, or because the respective information contained in the price and quantity variables overlaps.

The second aspect. of Porter and Offenbacher's paper with which I disagree is their presumption that the theoretical foundation underlying the relationship to nonfinancial economic activity of M1 or M2 is more substantial than that for credit. To be sure, there are many models of the demand for money for transactions purposes, as well as of the demand for asset holding. Neither set of models, however, necessarily matches up with the M1 or M2 aggregates in the circumstances prevailing in today's financial markets. The deposits and currency included in M1 are hardly the only way of effecting transactions, and M2 is far from identical to total liquid assets. Failing these conditions, what is needed is a more general theory describing the holding of inside assets, and in particular relating inside asset holding to the determination of nonfinancial economic activity. In the end, however, theories of inside asset holding are inseparable from theories of inside liability issuing.

Among the familiar financial aggregates, the only one for which a genuinely well worked out theory

\footnotetext{
${ }^{7}$ In addition to the possible implications given here, there is always the possibility that the interest rate merely appears to be important in this context because of the well-known forecast element in asset prices; see, for example, Sims (1982). This possibility is greater the longer is the term of the asset in question.
} 
exists to relate it to nonfinancial economic activity is the monetary base. Models in which all assets are outside assets, and (inside) liabilities do not exist, have been a staple of macroeconomics for decades, and at the theoretical level they have delivered many valuable insights. Whether such models are helpful in choosing an aggregate target for monetary policy is another question. The world they describe corresponds to a modern economy only if inside assets and liabilities exist but do not much matter. The empirical evidence relating the monetary base to nonfinancial economic activity suggests 'that' that is not so.

Apart from the monetary base, there is little way of choosing for this purpose from among today's plethora of financial aggregates on purely theoretical grounds. The practical question of what aggregate(s) to use as the target(s) of monetary policy-again, if any are to be used at all-is an empirical issue. The approach I took to address this issue was to employ a variety of statistical approaches that previous researchers had claimed offered empirical support for using one or another money aggregate target and to attempt to show that, on balance, they provided about the same support for using a total net credit target'. The vector autoregression methods on which 'Porter and Offenbacher focus were one of several such approaches to which I turned in this spirit.

Porter and Offenbacher conclude their paper by saying that "the most that can be said in Friedman's favor is that VAR methods are not capable of distinguishing the proper monetary target." But that is exactly my point -along with the parallel finding that none of the other methods that I tried do so either. The empirical evidence, no matter how sorted, does not provide grounds for using a money target instead of a credit target (or vice versa). In the absence of any strong theoretical presumptions, one way or another, how can one choose money versus credit on the basis of the available evidence?

As Porter and Offenbacher partly acknowledge in their introduction, the Federal Reserve has recently resolved this issue by focusing on both money and credit. Probably the best way to view this change is as a response to the break-down of the traditional presumption favoring M1. In October 1982, Federal Reserve Chairman Paul Volcker announced a suspension of the M1 target-in other words, a monetary policy which deliberately moved in the direction opposite to what would have been needed to restore' M1 to (or even near) its 1982 target growth range. In February 1983, the Federal Reserve included in its formal report to Congress the "associated range" for total net credit that Porter and Offenbacher mention. In July 1983, the Federal Reserve reported to 'Congress that it had chosen to change the 1983 target growth range for M1 rather than pursue a policy which. would restore M1 to (or near) the initially stated target range. At the same time, it reclassified the ranges for both $\mathrm{M} 1$ and total net credit as "monitoring ranges." Porter and Offenbacher simply do not say whether they agree with these successive steps. ${ }^{8}$ I believe that they were an appropriate response to the situation and the evidence at hand.

\section{Value of the Vector Autoregression Method}

Finally, a largely methodological issue that Porter and Offenbacher raise is whether vector autoregression analysis can usefully address policy question like those I have discussed above (or, indeed, any others). Along with the finding by Porter and Offenbacher of great sensitivity to apparently, small and arbitrary details, there is the "broader, issue of whether vector autoregression methods are capable of judging what would happen under a new policy regime because the regime change itself would in general alter whatever structure underlies the vector autoregression. ${ }^{9}$ At the same time, Sims has argued that these methods are typically more robust than Porter and Offenbacher find, as well as that regime changes of the kind that would pose such fundamental problems do not represent the best way of thinking about practical policy choices. ${ }^{10}$

This reply is not the right place for a methodological discussion of the issues involved here. Moreover, I remain agnostic on the subject in any case. That is why I used not only vector autoregression analysis but other forms of evidence, as well as nonempirical arguments, to make a case for including a total net credit target in the monetary policy process. My objective in the work on which Porter and Offenbacher focus was to be as methodologically catholic

\footnotetext{
${ }^{8}$ Even so, the evolution of the successive drafts of the Porter-Offenbacher paper present an interesting case study of the interaction between research and policymaking in a bureaucratic setting. The earliest draft that I received from the authors, written before the October 1982 suspension, maintained the implicit but nonetheless clear presumption that M1 was the right target, and took the question at issue to be whether anything in the empirical evidence was sufficient to change that presumption. The presumption in favor of M1 has gradually, disappeared from subsequent drafts, so that the final version in fact gives the stencil of the evidence the same coloring I do.

${ }^{9}$ See, for example, McCallum (1983).

${ }^{10}$ See again Sims (1982).
} 
as possible. Beyond that, it was to play, deliberately, on "the other team's turf"-that is, to use forms of evidence on which other researchers, who had claimed a special positive and/or policy role for some monetary aggregate, had relied to support their claims. I concluded that this evidence is equally supportive of a role for total net credit. I think Porter and Offenbacher agree.

\section{References}

Clarida, Richard H., and Benjamin M. Friedman. "A Statistical Analysis of the Behavior of U.S. ShortTerm Interest Rates." Journal of Finance, forthcoming 1984.

Friedman, Benjamin M. "Targets, Instruments and Indicators of Monetary Policy." Journal of Monetary Economics 1 (October 1975), 443-73.
"The Inefficiency of Short-Run Monetary Target's for Monetary Policy." Brookings Papers on Economic Activity, 1977:2, pp. 293-335.

"The Roles of Money and Credit in Macroeconomic Analysis." Tobin (ed.), Macroeconomics, Prices and Quantities: Essays in Memory of Arthur M. Okun. Washington: The Brookings Institution, 1983.

McCallum, Bennett T. "Macroeconomics after a Decade of Rational Expectations: Some Critical Issues." Federal Reserve Bank of Richmond, Economic Review 68 (November/December 1982), 3-12.

Mehra, Yash P. "Is Money Exogenous in MoneyDemand Equations Journal of Political Economy 86 (April 1978), 211-28.

Sims, Christopher A. "Comparison of Interwar and Postwar Business Cycles : Monetarism Revisited." American Economic Review 70 (May 1980), 250-57.

"Policy Analysis with Econometric Models." Brookings Papers on Economic Activity, 1982:1, pp. 107-52. 


\title{
RESPONSE TO FRIEDMAN
}

\author{
Richard D. Porter and Edward K. O ffenbacher
}

Professor Friedman restates his three reasons for adding credit to the list of intermediate targets for monetary policy: (1) policymakers should broaden their sources of information to include observations on both the asset and liability sides of the public's balance sheet; (2) the domestic nonfinancial credit aggregate (DNF) bears as close a relationship to nonfinancial economic activity as does any conventional monetary aggregate; and (3) ultimately this credit measure can be controlled by the Federal Reserve with about as much precision as any conventional monetary aggregate. In our response to Friedman we will focus on the second point since it is the major theme of our paper.

The empirical evidence analyzed by Friedman consists primarily of in-sample comparisons of monetary aggregates and a domestic nonfinancial credit aggregate for a variety of nonstructural statistical relationships: (a) coefficients of variation for the inverse of velocity; (b) St. Louis reduced-form equations; and (c) impulse response functions and variance decompositions derived from vector autoregressions. Friedman recognizes that the VAR approach may be more useful than either (a) or (b) for discovering regularities in the data because it allows for a richer dynamic specification of the interaction among vari- ables. ${ }^{1}$ However, our empirical results suggest that the VAR methods are not robust to even small changes in the specification. For example, after 16 quarters the bivariate impulse response function for domestic nonfinancial debt ranges from -.19 to 1.12 depending both on the ordering of the variables and on the choice of quarterly average or end-of-quarter data; or, M1's bivariate impulse response function after two quarters is either .05 or .63 depending on the ordering. In contrast to Friedman, such results do not lead us to conclude that credit and monetary aggregates are on an equal footing. After all, what can one learn from a procedure that cannot discriminate among alternative hypotheses?

Missing from Friedman's list of empirical comparisons is any reference to a structural model which may be presumed to be invariant to changes in monetary policy. The choice among monetary aggregates with stable demand functions as intermediate targets may be made along lines developed by Poole [1970], assuming that the ultimate objective is to minimize fluctuations in nominal income. In two recent theoretical papers, Papademos and Modigliani, have sought to extend this analysis to include debt

\footnotetext{
${ }^{1}$ Friedman [1983], pp. 122-23.
} 
instruments. We think that the debate concerning money and credit aggregates would be elevated considerably if the empirical work were able to produce estimates of the structural parameters in the Papademos-Modigliani model. Without a structural explanation of domestic nonfinancial credit, it is difficult to evaluate the behavior of the ratio of DNF to GNP. For example, does the recent departure of this ratio from 144 percent of GNP signify a permanent or a transitory change in its velocity level? Detailed structural work should be able to resolve such questions and, more importantly, shed some light on the conditions under which a credit aggregate could be expected to supplement information on monetary aggregates.

\section{References}

Friedman, Benjamin M., "Monetary Policy With a Credit Aggregate Target," in Karl Brunner and Allan H. Meltzer (eds.), Money, Monetary Policy, and Financial Institutions (Supplement no. 18 to Journal of Monetary Economics), Amsterdam: North-Holland Publishing Co., 1983.

Modigliani, Franco and Lucas D. Papademos, "The Structure of Financial Markets and the Monetary Mechanism," in Controlling Monetary Aggregates III, Conference Series no. 23, Federal Reserve Bank of Boston, 1980, pp. 111-55.

Papademos, Lucas and Franco Modigliani, "Inflation, Financial and Fiscal Structure, and the Monetary Mechanism," European Economic Review, (1983) vol. 21 , pp. $203-50$.

Poole, William, "Optimal Choice of Monetary Policy Instruments in a Simple Stochastic Macro Model," Quarterly Journal of Economics, vol. 84 (May 1970) $197-216$.

The Economic Review is produced by the Research Department of the Federal Reserve Bank of Richmond. Subscriptions are available to the public without charge. Address inquiries to Public Services, Federal Reserve Bank of Richmond, P.0. Box 27622, Richmond, Virginia 23261. Articles may be reproduced if source is given. Please provide the Bank's Research Department with a copy of any publication in which an article is used. Also note that microfilm copies of the ECONOMIC Review are available for purchase from University Microfilms, Ann Arbor, Michigan 48106. The identification number is 5080 . 